\title{
A revision of Themeda (Gramineae) in Malesia with a new species from Laos
}

\author{
J.F. Veldkamp ${ }^{1}$
}

\author{
In memory of Bryan Kenneth Simon (1943-2015)
}

\section{Key words}

lectotypification

Thailand

\begin{abstract}
Themeda Forssk. (Gramineae) has 11 taxa in Malesia. A revision is provided with keys, synonymy, where necessary lectotypifications, descriptions, and notes. Themeda gigantea nearly is a Philippine endemic, but with a single collection from Halmahera, and one as far away as the Solomon Islands. Themeda caudata is reduced to T. villosa var. caudata, comb. nov., and T. intermedia to T. villosa var. polyantha, comb. nov. Themeda polycephala, a new species, is described from Laos. Themeda hookeri is a new record for Thailand.
\end{abstract}

Published on 16 March 2016

\section{INTRODUCTION}

The genus Themeda Forssk. (Gramineae, Andropogoneae) has about 27 species in the (sub)tropical grasslands of the Old World (Clayton et al. 2014). Some giant species (up to $6 \mathrm{~m}$ tall) may be vegetation forming and dominate grass wildernesses nearly impenetrable because of their razor sharp leaves, while the pungent calli of the fertile spikelets penetrate clothing and skin. Still, with their huge, pendulous inflorescences they are quite decorative.

Hackel (1889: 656) already complained "in nullo certe genere nomina specierum magis confusa quam in Anthistiria [= Themeda]" ("Without any doubt [there is] no genus where the names of the species are more confused than in Anthistiria") and this is shown by the impressive synonymy, to which he himself significantly contributed, and was also experienced here.

\section{HISTORY}

Forsskåhl (1775) described the genus with only Themeda triandra. He derived the generic name from the Yemeni word Thaemed. According to an anonymous source on the internet this would allude to "a depression in which water lies after rain, subsequently drying in summer". The reason for the epithet is not clear, it is quite usual for a grass floret to have three stamens, while, alternatively, there are not three but four reduced spikelets forming an involucre in the partial inflorescence here. This was not the first species that was known to Western science. At least one was already described and depicted by Rumphius (1750): Gramen arguens Rumph., validated by Linnaeus (1762: 117) as Stipa arguens L.

Another may be Calamagrostis Rumph. It is not certain whether it is a Themeda at all. Rumphius described it as a giant grass forming tussocks behind which one can hide, or dense shrubbery which can conceal wild animals. He compared it to his Arundo farcta [= Miscanthus floridulus (Labill.) Warb.] and 'siree', i.e. 'sereh', Lemongrass, Cymbopogon citratus (DC.) Stapf, but said it served no purpose at all. Local uses included that as of $T$. arguens and in decorative wedding arches. The

\footnotetext{
Naturalis Biodiversity Center, section Botany, P.O. Box 9517, 2300 RA Leiden, The Netherlands; jef.veldkamp@naturalis.nl.
}

illustration is rather crude, and it is no wonder that Linnaeus (1762: 65) cited it under Schoenus lithospermus L. (= Scleria lithosperma (L.) Sw., Cyperaceae). It was regarded as T. gigantea by Merrill (1917). This is erroneous, as that species is a Philippine near-endemic. The only giant species of Themeda known to me from Ambon is T. villosa (Poir.) A.Camus var. polyantha (Brongn. ex Buse) Veldk.

Another species cultivated in the Uppsala Botanical Garden with unknown provenance was described by Linnaeus (1771) as Andropogon nutans, a combination he already had used in 1753 for an American species, now Sorghastrum nutans (L.) Nash (Veldkamp 1984). In 1774 he renamed this to Andropogon quadrivalvis L.

Houttuyn (1782) under Stipa arguens noted a curious grass that he had received from Thunberg collected in Japan, which in no way, he noted, could be the same as Linnaeus's species. He provided a beautiful illustration, but no name. His specimen is in G. Thunberg $(1784 a, b)$ described his duplicate in UPS as Andropogon ciliatum Thunb. and Willdenow (1806), based on the one in B, as Anthistiria japonica, providing an epithet that has been in current use as T. japonica. Desfontaines (1792) renamed it to Anthistiria barbata. The involved nomenclature surrounding these collections and the names based on them is explained elsewhere (Veldkamp 2015) with as conclusion that the correct name for T. japonica is T. barbata (Desf.) Veldk.

The publication by Forsskåhl was overlooked by Naezén (1779) who in a PhD thesis under Linnaeus f. described Anthistiria with an illustration of bristled involucral spikelets, but without a species. Contrary to most Linnean theses which are to be attributed to either Linnaeus pater or filius, he is to be considered as the author of this one (Krok, cited by Stafleu \& Cowan 1981). The origin of the name was not given but seems derived from

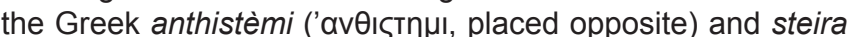

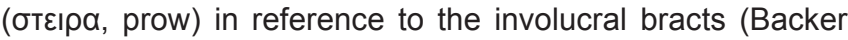
1936: 31). This was the generic name in general use until the end of the 19th century.

For some reason some later authors wrote this as Anthesteria, e.g. Sprengel $(1817,1824)$, Trinius (1832), C.B. Presl (1833), Hasskarl (1843). Steudel (1854b) noted that this would refer to the 'av $\theta \varepsilon \varsigma$ тnpıа, the holy feasts, bacchanalia, of Bacchus (God of vine growing and harvesting, wine, intoxication, ritual madness, religious ecstasy, theatre, and fertility). He is often 
depicted with a crown of vine leaves and this might be an allusion to the involucral spikelets. Whatever, Naezén is to be followed, and Anthesteria, although probably intended as an orthographic correction has a different derivation and is a superfluous name.

The specific combination for Naezén's plant was provided by his supervisor Linnaeus f. (1782), A. ciliata, a clear superfluous name for Andropogon nutans L. (1771) and A. quadrivalvis. Yet, the epithet 'ciliata' remained long in use, e.g. by Camus (1920a, b, 1922) and Roberty (1960).

Retzius (1783) accepted Anthistiria ciliata and described Anthistiria imberbis. For some reason later authors, possibly because Andersson (1856) did so, cited Retzius as author of the first combination.

Cavanilles (1799) described and depicted Anthistiria gigantea from Luzon which later caused widespread confusions with T. arundinacea (Roxb.) A.Camus, T. caudata (Nees) A.Camus, T. idjenensis Jansen, T. novoguineensis (Reeder) Jansen, and T. villosa (Poir.) A.Camus (incl. T. intermedia (Hack.) Bor), some sometimes regarded as varieties of it. It is here regarded as a Philippine near-endemic.

Palisot de Beauvois (1812) described Calamina with 5 species. He was obviously confused by the identity of $A$. gigantea, as he based his $C$. gigantea on it, but the illustration (t. 23, f. 1) clearly is Apluda mutica L., whereby it is the obvious lectotype and Calamina is superfluous for Apluda L. (Art. 52.1, McNeill et al. 2012). There may be an error of citation here, as so many others in this work, and Beauvois may have actually intended to depict C. mutica (L.) P.Beauv. based on Apluda mutica. He also included Calamina sehima, doubtfully based on Sehima ischaemoides Forssk., the type of Sehima Forssk. Roemer \& Schultes (1817) accepted the name, reduced the number of species to 3 , and although with some doubt retained $C$. mutica (L.) P.Beauv.

Gradually more species were discovered and described. Sprengel (1824) enumerated 15 in Anthesteria and distinguished two unranked taxa: Aristatae Spreng. and Muticae Spreng. with only Anthisteria gigantea (Cav.) Spreng. He apparently realised the confusion caused by Beauvois and tried to solve it by moving Calamina gigantea to Apluda gigantea (P.Beauv.) Spreng.

Kunth (1829) cited 20 species, although of 6 he did now know what the names represented.

J. Presl (1830) also misinterpreted Anthistiria 'Linn.' and described and depicted next to Anthistiria tortilis J.Presl (= Cymbopogon tortilis (J.Presl) A.Camus) from Luzon and A. pilosa J.Presl (= Hyparrhenia bracteata (Humb. \& Bonpl. ex Willd.) Stapf) from Peru, the new genus Perobachne with $P$. secunda (= T. gigantea (Cav.) Hack.) from Luzon. Perobachne seems

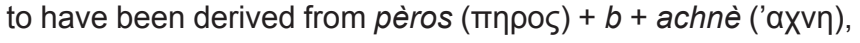
mutilated chaff, for the upper lemma is not awned, or the awn is short (up $3.5 \mathrm{~cm}$ long) (Backer 1936: 435).

Brongniart (1831) erected Androscepia for Anthistiria gigantea Cav. seeing it as similar to but different from Anthistiria. Andros ('avס̄os, man or male), scepè (бкєாฤ, involucre) for the involucre of male spikelets.

Endlicher (1836) reduced Androscepia to Perobachne. No specific combinations were proposed then, and none later.

Junghuhn (1840: 294) described Heterelyteron with H. scabrum, now T. villosa (Poir.) A.Camus var. villosa. The name is derived

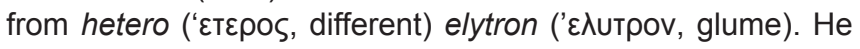
also proposed Aristaria (1840: 296), for the long awns (arista), with $A$. barbata Jungh., now $T$. arguens (L.) Hack.

Steudel (1854b) accepted Androscepia (1 sp), Anthistiria (38, incl. Themeda), Heterelytron (1), and Perobachne (1).
The next revision was by Andersson (1856) with Anthistiria and Androscepia (incl. Perobachne). The latter union for priority reasons should have been the other way around. He cited Endlicher (1836), but did not follow him. He distinguished the two genera by the number of sessile and pedicelled spikelets, an untenable approach. In Anthistiria he distinguished some infrageneric rankless entities: Chrysanthistiria Andersson, Euanthistiria Andersson, and Heterelytron (Jungh.) Andersson. He studied material in at least B, S, UPS, W, but only exceptionally mentioned the herbarium where he saw what. The whereabouts of his types is therefore unknown. No Themeda types were found in UPS (R. Moberg in litt., 8 Apr. 1999). He most likely saw at least Junghuhn specimens in $B$, but all andropogonoids there have been destroyed $(\mathrm{H}$. Scholz, in litt.).

Bentham \& Hooker f. (1883) drastically reduced several genera to the synonymy of Anthistiria, not giving them any rank: Androscepia Andersson, Exotheca Andersson, Germainia Balansa \& Poitr. ('Germainea'), Iseilema Andersson. This was followed by few.

Hackel (1887: 29) accepted Anthistiria, including Androscepia, Heterelytron, and Perobachne, accepting 9 species. In the Errata (p. 126) he realised that Themeda was the earliest name. He gave an extensive revision in 1889 , without an infrageneric classification, if one discounts his key, and distinguished 8 species, 6 subspecies, 23 varieties, and 5 subvarieties. Because this monumental work is often the last word on Andropogoneae his classification is widely accepted until today.

Ms. Camus (1920a, b) also gave a survey of Themeda without infrageneric groups, but with 11 species, 8 subspecies, 29 varieties, and 7 subvarieties.

Pilger (1940) gave a brief summary in which he recognised 6 species.

Roberty's (1960) numerological, non-Linnaean classification is mentioned for the record. He partly followed Bentham \& Hookerf.'s classification and distinguished 4 sections, reducing Iseilema, Germainia, and Pleiadelphia Stapf. In sect. Themeda he had 9 species, 4 varieties, 24 subvarieties, and 3 formae.

Chen \& Zhuang in Zhuang \& Chen (1989) recognised two sections based on the relative position of the involucral spikelets and number spikelets in an involucre: Primothemedae for the species with the pairs of involucral spikelets unequally inserted, and Themeda for the equally inserted ones. They cited T. japonica (Willd.) Tanaka as its type, an obvious error for T. triandra.

Zhao (1998) enumerated 31 species and 13 varieties of T. triandra, but did not mention the sections of Chen \& Zhuang.

\section{MORPHOLOGY}

The dimensions of the ligules, leaves, especially their length in the larger species, had to be taken from the literature. Often no obviously mature ones were seen.

Perhaps there is a character in the pubescence of the margin of the ligule, but in practice the ligule is hard to find and easily tears in dissection.

Grasses rarely have bracts in their inflorescences, but in this alliance the branches are supported by so-called spathas, while the ultimate spatha supporting the partial inflorescence is here called the spatheole. Probably because it is an Old World genus, Themeda is underrepresented in molecular phylogenetic analyses. The spathaceous genera of the Andropogoneae Anthistiriinae J.Presl sensu Clayton \& Renvoize (1986) are not a monophyletic clade (Skendzic et al. 2007).

Kellogg \& Watson (1993: f. 8) had Themeda in a clade with Apluda, Apocopis Nees, Hyperthelia Clayton, Iseilema, and Pseudanthistiria (Hack.) Hook.f. 
Skendzic et al. (2007: f. 3) found Themeda in a small clade consisting also of Chrysopogon Trin. (incl. Vetiveria Bory), Heteropogon Pers., and Iseilema.

Welker et al. (2015) in a sample study found Themeda and Heteropogon ending up together next to a clade with species of Bothriochloa Kuntze, Capillipedium Stapf, Dichanthium Willemet, and Iseilema.

In the subtribe the inflorescences are composed of single or paired racemes, which in many species of Themeda can attain gigantic proportions and the actual composition is not obvious, obscured by the many spathas and partial branches. Because of the mere size of several meters it is only partially collected. In this alliance the ultimate inflorescence usually consists of two racemes, one more or less sessile/terminal on the peduncle, the other variously stalked. Both at base may have one to several paired spikelets reduced to the glumes, the 'homogamous' spikelets. In Themeda the racemes are perhaps also paired as there are two pairs of opposite involucral (homogamous) spikelets, where distichous ones would be expected in a single inflorescence. I have therefore used the term 'capitule' here. Sometimes (Primothemedae) there is a short distance between the two pairs: one perhaps representing the terminal raceme, the other the lateral one. That this is not an 'easy' character is exemplified by T. quadrivalvis, which Bor in 1960 said has the pairs of spikelets at the same level, but in 1970 with an internode of 5-8 $\mathrm{mm}$. The first observation is correct and I have never seen any internode that long, it is usually less than $1 \mathrm{~mm}$. The arrangement of the other spikelets is of the usual andropogonoid type: they are paired with one sessile (bisexual) and one (male) spikelet with a terminal triplet of one sessile and two pedicelled spikelets. In some species only the triad is present.

In $T$. arguens the involucral and pedicelled spikelets are reduced to a single glume and not very obvious among the close-set spatheoles and fertile florets. One has to know that this is a Themeda to see them, as they are small, membranous. They differ by their apices: oblique and/or erose in the involucral ones, acuminate to aristate in the pedicelled ones.

It is also hard to see whether involucral and pedicelled spikelets have a lemma and palea, as these are very thin and translucent, and usually tightly clasped by the glumes.

The presence of an awn and its length is an important (being easy) character, but not so easy as it is often deciduous and an apparently unawned specimen may have some persistent awns hidden somewhere. It may not be ruled out that in some cases awned and unawned individuals are not actually part of a range of variation of a single taxon. I have my suspicions in T. villosa var. villosa, var. caudata, and var. polyantha.

The sex of the involucral and pedicelled spikelets is often in doubt, too, as the anthers apparently are soon shed. Soaking in water with some detergent is an easy way to reveal them.

\section{Uses}

See under the species.

\section{THEMEDA}

Themeda Forssk. (1775) 178; N.Zhao (1998) 293. - Type: Themeda triandra Forssk.

Anthistiria Naezén (1779) 35; (1790) 38, t. 1; Andersson (1856) 232, incl. [rankless] Euanthistiria Andersson, nom. inval. — [Anthistiria Naezén subsect. Euanthistiria (Andersson) Andersson ex Benth. \& Hook.f. (1883) 1136, nom. inval.]. - Anthesteria Spreng. (1817) 179, nom. superfl. - Type: Anthistiria ciliata L.f., nom. superfl. [= Themeda quadrivalvis (L.) Kuntze]. Perobachne J.Presl (1830) 348. - Type: Perobachne secunda J.Presl [= Themeda gigantea (Cav.) Hack.].

Androscepia Brongn. (1831 '1829') 77. - Type: Androscepia gigantea (Cav.) Brongn. [= Themeda gigantea (Cav.) Hack.].
Aristaria Jungh. (1840) 296. - Type: Aristaria barbata Jungh. [= Themeda arguens (L.) Hack.].

Heterelytron Jungh. (1840) 294. - Anthistiria Naezén [rankless] Heterelytron (Jungh.)Andersson (1856)233. - Type: Heterelytron scabrum Jungh. [= Themeda villosa (Poir.) A.Camus].

Anthistiria Naezén [rankless] Chrysanthistiria Andersson (1856) 244. - Anthistiria Naezén subsect. Chrysanthistiria (Andersson) Andersson ex Benth. \& Hook.f. (1883) 1136. - Lectotype: Anthistiria vulpina Andersson [= Themeda arundinacea (Roxb.) A.Camus], designated here.

Themeda Forssk. sect. Primothemedae S.L.Chen \& T.D.Zhuang in Zhuang \& Chen (1989) 55. - Type: Themeda unica S.L.Chen \& T.D.Zhuang.

[Calamagrostis Rumph. (1750) 16. — Voucher: none [?= Themeda villosa Poir.) A.Camus var. polyantha (Brongn. ex Buse) Veldk. ex descr.]. Calamina auct. non P.Beauv.: P.Beauv. (1812) 128, 157, excl. Apluda mutica L.

Annuals or perennials. Culms solid. Ligule collar-shaped, membranous. Inflorescence paniculate, spatheate, decompound, spikelet-bearing axes very much reduced, clustered in capitules supported by a spatheole, usually persistent, involucre formed by 2 homogamous involucral pairs of male or sterile (sub)sessile spikelets. Rachis disarticulating at the base of the fertile spikelets. Fertile spikelets 1-4, bisexual, callus pungent; lower glumes flat on the back, 9-11-nerved; callus hairy, acute to acuminate (absent in T. gigantea). Awns (when present) apical, stipitate. Pedicels free of the joints. Pedicelled spikelets variously reduced. $x=10$.

Distribution - c. 27 species, 10 in Malesia.

\section{KEY TO THE TAXA}

Note - The 'peduncle' is that of the capitule. Fertile spikelets and awns may be early deciduous! 'Unequally' inserted pairs of involucral spikelets mean that there is a distance of c. $1 \mathrm{~mm}$ between the pairs; the spikelets of the pair are unequally pedicelled! Perfect awns have clear differences between the column and the arista.

1. Involucral spikelets lower glumes well-developed, conspicuous, herbaceous, 9- or 11-nerved . . . . . . . . . 2

1. Involucral spikelets lower glumes inconspicuous, small, hidden among the spatheoles, membranous, 5- or 7-nerved. Peduncle extremely short, white hairy. Pairs of involucral spikelets inserted at the same level, sterile, lower glumes $5-9.5 \mathrm{~mm}$ long, glabrous ... . . . . . . . . 1. T. arguens

2. Pairs of involucral spikelets inserted at the same level . . 3

2. Pairs of involucral spikelets unequally inserted . . . . . . 4

3. Plants annual. Involucral spikelets lower glumes 4-7 mm long, acute to abruptly obliquely apiculate. Callus hairs 1.7-2.5 mm long. - Sumba, Timor, ?Papua New Guinea $\ldots \ldots \ldots \ldots \ldots \ldots \ldots \ldots .6$. . T. quadrivalvis

3. Plants perennial. Involucral spikelets lower glumes 7-14 $(-20) \mathrm{mm}$ long, acuminate. Callus hairs $3-4.5 \mathrm{~mm}$ long. .

7. T. triandra

4. Involucral spikelets lower glumes hirsute (hairs sometimes

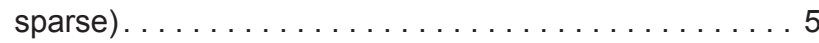

4. Involucral spikelets lower glumes not hirsute . . . . . 7

5. Awn absent (careful: sometimes early deciduous!) or very short (column more or less straight). Pedicelled spikelets pedicel hairy. . . . . . . . . . . . . . . . . 6

5. Awn well-developed. Pedicelled spikelets pedicel glabrous. - Peduncle 3-20 mm long, extremely short to c. 1/2 as long as the spatheole. Capitule long-persistent. Fertile spikelets 1-2. Pedicelled spikelets $13-17 \mathrm{~mm}$ long .......... . . . . . . . . . . . . . . . . 2. T. arundinacea

6. Peduncle 1-2 mm long; extremely short. Capitule falling as a whole. Fertile spikelets 1. Pedicelled spikelets 7-9 mm long. - More or less endemic to the Philippines 
6. Peduncle $10-14 \mathrm{~mm}$ long; $1 / 3-1 / 2$ times as long as the spatheole. Capitule long-persistent. Fertile spikelets $2-3$. Pedicelled spikelets $11-14 \mathrm{~mm}$ long.

8c. T. villosa var. polyantha

7. Fertile spikelets 1. Pedicelled spikelets $2 \ldots \ldots \ldots 8$

7. Fertile spikelets $2-3$. Pedicelled spikelets $3-4 \ldots \ldots$. . 9

8. Ligule 2-3 mm long. Involucral spikelets lower glumes $12-$ $16 \mathrm{~mm}$ long. Fertile spikelets $10-11 \mathrm{~mm}$ long (incl. callus). Pedicelled spikelets 10-16 mm long; lower glumes apex mucronate to aristate . . ........... 4. T. idjenensis

8. Ligule 1-1.2 mm long. Involucral spikelets lower glumes 6.5-10 mm long. Fertile spikelets 7-9 mm long (incl. callus). Pedicelled spikelets 6-8.5 mm long; lower glumes apex acuminate. - Papua New Guinea (Central Prov.) . . . . . .

5. T. novoguineensis

9. Awn well-developed, perfect, 23-60 mm long, column twisted, 12-37 mm long (i.s.) . . . . 8b. T. villosa var. caudata

9. Awn absent (careful: sometimes early deciduous!) or very short, 0(-32) mm long, column more or less straight, 0-14 $\mathrm{mm}$ long (i.s.) . . . . . . . . 8a. T. villosa var. villosa

\section{Themeda arguens (L.) Hack.}

Themeda arguens (L.) Hack. (1889) 657. - [Gramen arguens or Tagalnana Rumph. (1750) 15, t. 6, f. 1, nom. inval.]. - Stipa arguens L. (1762) 117. Anthistiria arguens (L.) Willd. (1806) 901. — Anthistiria ciliata Naezén var. major Thwaites (1864) 366, pro comb. - Themeda forskalii Hack. var. major (Thwaites) Hack. (1889) 662, pro comb., non Anthistiria (Themeda) forskalii Kunth ('Hack.') var. major Duthie (1888). — Anthistiria imberbis Retz. var. major (Thwaites) Hook.f. (1896) 213. - Themeda triandra Forssk. var. major (Thwaites) Domin (1915) 279. - [Themeda arguens (L.) Hack. var. genuina A.Camus (1920a) 267, nom. inval.]. — Lectotype: Burman in Herb. Linn. 94.10 (LINN, IDC microfiche), indirectly designated by Merrill (1917: 89), more directly by Henrard (1941: 522 ), and specifically by Jarvis (2007: 875).

Anthistiria frondosa R.Br. (1810) 200. - Anthesteria frondosa (R.Br.) R.Br. ex Spreng. (1824) 291. - Themeda frondosa (R.Br.) Merr. (1917) 89. — Lectotype: R. Brown 6195 (BM, photo K, BRI; iso K), designated here.

Aristaria barbata Jungh. (1840) 297. - Type: Not resolved, "per totam insulam (Java) locis apricis siccis vulgare, a mare usque ad 2000'. Nomen: rambut kassan, djukut djurin." (not found in L).

Anthistiria ciliata Naezén var. glabrescens Buse (Feb. 1854) 23; (Aug. 1854) 363. - Type: Junghuhn s.n. 'montem Madinang'(holo L sh. 903.342-232). Anthistiria pilifera Steud. ((June 1854a) 58, nomen) (July 1854b) 400. — Lectotype: Zollinger 373 (P; iso G, L sh. 903.342-223), designated here.

Anthistiria junghuhniana Nees var. altior Andersson (1856) 233. - Type: Junghuhn s.n. 'In rupibus montis Gunong Mandjesinang' (= Mandjinnang) (iso L sh. 903.342-234).

Anthistiria junghuhniana Nees var. minor Andersson (1856) 233. - Type: Junghuhn s.n. 'Ad Tjibogo' (iso L sh. 903.342-224, -227, -229, -233).

Themeda arguens (L.) Hack. var. balinensis Jansen (1952) 479. - Type: Van Steenis 7763a (holo BO1901668).

Andropogon tropicus auct. non Spreng.

Anthesteria arundinacea auct. non Hassk.

Anthistiria arundinacea auct. non Roxb.

Themeda caudata auct. non A.Camus.

Themeda ciliata auct. non Naezén.

Etymology. 'arguens' ('arguo', Lat.), 'reproaching'. Rumphius wrote: “Its use in medicine is up to now unknown, although with the Ternatans there is a childish but common use. When one wants to accuse or reproach somebody else, especially the lovers, or the woman her man, or the man his woman, that one because of the other must suffer some grievance, sorrow, or burden, then they send him a little present wrapped in the spiny spikes of this growth, wanting to let the other know through the name of this herb, that they must suffer some sorrow because of his sake, when they want to make clear this meaning: I must through your will suffer sorrow, then he adds the herb Gratiola or Daun tsjinta (Phyllanthus niruri L.), which with its sad face in the evening means sorrow (the leaves show profound nyctinasty), and add this together with the spikes, which they then send to each other".

Plants annual to perennial. Culms $0.35-2 \mathrm{~m}$ long, with a creeping rhizome to tufted. Nodes glabrous. Ligule 1-2 mm long, margin glabrous. Leaves $5-45 \mathrm{~cm}$ by $3.5-6 \mathrm{~mm}$. Uppermost spatheoles glabrous or white hairy. Peduncle 0.5-2 mm long, extremely short, white hairy. Involucre persistent, involucral spikelets inconspicuous, small, hidden among the spatheoles, pairs inserted at the same level, sterile, lanceolate, $5-9.5$ by $0.3-0.5(-1) \mathrm{mm}$, membranous, 5-7-nerved, glabrous. Fertile spikelets 1, 7-10 mm long (incl. callus), callus $0.8-2 \mathrm{~mm}$ long, pilose, hairs brown, 4.5-5 mm long. Lower glumes castaneous, apex truncate, surface distally hispidulous. Awn perfect, 35-120 mm long, column 25-65 mm long (i.s.), geniculate, hairs rufous (i.s.). Anthers $1.5-3 \mathrm{~mm}$ long, purple i.s. Pedicel glabrous. Pedicelled spikelets 0-2, 6-9 mm long. Glume apex acuminate to aristate, glabrous (v.v.). $2 n=20$.

Distribution - Andamans to $\mathrm{N}$ Vietnam and Australia (W Austr., N Terr., Queensland), Thailand (Eastern: Nakhon Ratchasima; Southwestern: Prachuap Khiri Khan, Rachaburi; Southeastern: Chonburi; Peninsular: Trang). Malesia: Mal. Penins. (Johor, Kedah, Malacca, Negeri Sembilan, Penang, Perak, Selangor), Singapore, Sumatra (Aceh, E-, W Coast), Bangka, Natuna Isl., Java (widespread), Bawean Isl., Madura, Kangean Arch., Lesser Sunda Isl. (Bali, Flores, Komodo, Sumba, Sumbawa, Timor), Anambas Isl., Borneo (W Kalimantan, Pontianak, Sabah), Celebes (Makassar, Manado, Palu), Talaud Isl., Philippines (Luzon, Mindanao, Mindoro), Moluccas (Ambon, Ceram, Ternate), New Guinea (widespread). Introduced elsewhere, e.g. Cuba, Fiji, Jamaica, Puerto Rico, USA (Maryland, Virginia).

Habitat - Very common and widespread weed of sunny, dry roadsides, ruderal places, grassy areas, Tectona- and savannah forest, soil usually less fertile, in open areas often in huge numbers and after withering giving the field a characteristic brown to red glow. 0-1550 m altitude.

Vernacular name - Christmas grass, Lesser tasselgrass, Rumput merak.

Uses - Fodder of less than moderate quality. Young shoots eaten as a sweet-tasting vegetable, also against fever. Decoction of roots as a tonic, blood cleanser, restorer of virility. Leaves used against lumbago, rheumatism. Culms used for bird cages and traps. Inflorescences in dry bouquets. When put in clothing will creep and tickle. See also Etymology.

Collector's notes - Stems solitary to clumped, curved, ascending, purple red. Leaves pale to midgreen. Spatheoles green, often purplish at base. 'Flowers' green, brownish green, pale yellow. Fertile lemma with short brown hairs and longer brown hairs tufted at base. Awns purple, black.

Notes - There is some argument about the lectotypification of Stipa arguens L. The Linnaean collection (not named, but clearly LINN 94.10) was said by Munro (1862) to be Anthistiria ciliata, i.e. T. quadrivalvis, which was subsequently accepted by Merrill (1917) and Henrard (1941). However, examination by Savage \& Hubbard (in litt. to Jansen) and Cope (2000: 246) have shown that it is T. arguens. Merrill (1917: 89) wrote "The Linnean description was manifestly based on the specimen before him [Herb. Linn. 94.10], not on the Rumphian illustration; and, accordingly, the name should go with the plant he [Linnaeus] described", which seems like an implicit lectotypification. Henrard (1941) was more direct: "this type", and thus may be regarded to have designated it as the lectotype. Others have selected the reference to the Rumphius plate (Backer 1928: 110).

In $\mathrm{S}$ there is an Osbeck specimen without provenance, labelled 'Anthistiria' (and 'A. junghuhnianae'). This may have been seen by Linnaeus and Naezén, and the Linnaean specimen might even be a duplicate, but there is no proof of this.

Themeda arguens var. balinensis would differ by the folded leaf blades, sheaths glabrous but for the pubescent nodes and long-ciliate collar, short panicle with 1-2 few-spikeled clusters, glabrous to sparsely pilose spathes and glumes. 


\section{Themeda arundinacea (Roxb.) A.Camus}

Themeda arundinacea (Roxb.) A.Camus (1922) 363. - Anthistiria arundinacea Roxb. ((1814) 6, nomen); (1820) 256. - Cymbopogon arundinaceus (Roxb.) Schult. (1824) 457. - Anthesteria arundinacea (Roxb.) Roxb. ex Hassk. (1843) 118, pro comb. - Themeda gigantea (Cav.) Hack. subsp. \& var. arundinacea (Roxb.) Hack. (1889) 674. - Anthistiria gigantea Cav. subsp. arundinacea (Roxb.) Hack. ex Hook.f. (1896) 217. - [Themeda gigantea (Cav.) Hack. subvar. (Roxb.) arundinacea Roberty (1960) 89, nom. inval.]. - Type: Roxburgh s.n. (holo BM; BR, G; Icon. Ined. 1718: CAL, K). Anthistiria subsericans Nees ex Steud. (1854b) 401. - Anthistiria arundinacea Roxb. var. subsericans (Nees ex Steud.) Andersson (1856) 245. - Themeda gigantea (Cav.) Hack. subvar. subsericans (Nees ex Steud.) Hack. (1889) 674. - Themeda arundinacea (Roxb.) A.Camus var. subsericans (Nees ex Steud.) A.Camus (1922) 364. - Themeda subsericans (Nees ex Steud.) Ridl. (1925) 212. — [Themeda gigantea (Cav.) Hack. subvar. subsericans (Nees ex Steud.) Roberty (1960) 92, nom. inval.]. - Type: Herb. Wallich 8774-B (holo P; G, K, microfiche IDC 7394). Anthistiria vulpina Andersson (1856) 245. - Themeda gigantea (Cav.) Hack. var. vulpina (Andersson) Hack. (1889) 673. - Lectotype: Cuming 1272 (W, fragm. in L; iso L), first step designation by Jansen (1952: 481), second step here, see note.

[Themeda arundinacea Ridl. (1893) 401, nom. nud. - Voucher: Haviland s.n. (SING)].

Themeda intermedia (Hack.) Bor var. intorta Jansen (1952) 482. - Type: Van Loenen 16 (holo L sh. 950.264-084; BO1901669; SING), see note. Themeda gigantea auct. non Hack.

Plants perennial. Culms 1-6 m long, tufted. Nodes glabrous. Ligule c. $0.5 \mathrm{~mm}$ long, margin glabrous. Leaves $40-100 \mathrm{~cm}$ by 5-25 (or more) mm. Uppermost spatheoles glabrous. Peduncle 3-20 mm long, extremely short to c. $1 / 2$ times as long as the spatheole, glabrous to golden hairy. Capitules long-persistent. Involucral spikelets conspicuous, pairs unequally inserted, sterile to male; lower glumes linear-lanceolate, $12-20$ by $1-1.8$ $\mathrm{mm}$ wide, acuminate, herbaceous, 11-nerved, densely brown to golden hirsute (hairs sometimes bulbous based); upper glumes 3-nerved. Fertile spikelets 1-2, 9-11.5 mm long (incl. callus), callus 2-3.5 mm long, hairs brown, 2-3 mm long; lower glumes yellowish to castaneous, apex truncate, surface hairy all over, hairs white to castaneous. Awn well-developed, usually perfect, $20-110 \mathrm{~mm}$ long, column $20-80 \mathrm{~mm}$ long (i.s.), straight, minutely puberulous $(40 \times$ !) or scaberulous, hairs white (i.s.). Anthers 3.5-5.5 mm long, purple (i.s.). Pedicel glabrous. Pedicelled spikelets 2-3, male, 13-17 mm long; lower glumes apex acuminate, pilose. $2 n=40$.

Distribution - N India (Uttar Pradesh to Orissa) to S China (E to Guangxi), Thailand: (Northern: Chiang Mai, Lamphun; Northeastern: Loei; Central: Saraburi; Southeastern: Chantaburi; Peninsula: Krabi); Malesia: Sumatra (E Coast), Mal. Penins. (Kelantan, Pahang, Perak), W Java (Cikampek (Karawang), fide Backer 1928, see Beumée 1694a in BO, L. Misidentified T. villosa var. caudata), Borneo (Sabah), Lesser Sunda IsI. (Bali, Timor), Borneo (E-, SE Kalimantan, Sabah), Philippines (Luzon).

Habitat - Sunny slopes, roadsides, open forest, pine forest, river banks, edges of rice fields, $150-1375 \mathrm{~m}$ altitude.

Collector's notes - Culms 2-3.6 m, stramineous with tan hue, nodes blackish. Leaf $1 \mathrm{~m}$ long. Inflorescence pendent, axes pale tan-pinkish. 'Fruits' (= capitules) brown hairy, orange hairy, green. Awns dark brown. Anthers orange. Stigmas purple.

Notes - Andersson mentioned no provenance and no material for his Anthistiria vulpina. Hackel (1889: 673) cited Royle 234 or 240 (B, not clearly separated) from Nepal, while he commented: Cuming 1272 (W, fragm. in L) (from the Philippines) is annotated by Andersson himself and this is here accepted as the lectotype.

Themeda arundinacea Ridl. (1893) is not a new combination, but a new species, but it is a nom. nud. It is based on Haviland s.n., from the Malay Peninsula, Pahang, 'Pekan, open country'. Ridley later (1925: 212) cited this sub T. subsericans, based on misidentifications of $T$. arundinacea.

The taxonomic position of $T$. subsericans is not quite clear. Because of its similarity to $T$. arundinacea it has been regarded as 'a hybrid between $T$. arundinacea and $T$. villosa in which the spikelets are awned' (Bor 1960: 252). Jansen (1952: 481) retained it as a distinct variety of $T$. arundinacea, and Zhao (1998) and Noltie (2000: 820) as a distinct species. The latter thought it to be an 'upland' form of $T$. arundinacea. I see no good reason to maintain it.

Jansen described T. intermedia (Hack.) Bor var. intorta, but he correctly labelled the holotype as $T$. arundinacea (var. intorta).

\section{Themeda gigantea (Cav.) Hack.}

Themeda gigantea (Cav.) Hack. in Duthie (1888) 89; (1889) 670 [incl. subsp. \& var. genuina Hack., p. 672, nom. inval.]. - Anthistiria gigantea Cav. (1799) 36, t. 458. - Calamina gigantea (Cav.) P.Beauv. (1812) 128, 151, 157, excl. t. 23, f. 1; Cav. ex Roem. \& Schult. (1817) 810, isonym. - Anthesteria gigantea (Cav.) Cav. ex Spreng. (1824) 291. - Androscepia gigantea (Cav.) Brongn. (1831) 78. - [Androscepia gigantea (Cav.) Brongn. var. oligantha Buse (Feb. 1854) 24; (Aug. 1854) 364, nom. inval.]. - [Androscepia gigantea (Cav.) Brongn. var. mutica Andersson (1856) 248, nom. inval. pro var. gigantea]. - [Anthistiria gigantea Cav. subsp. genuina Hack. ex Hook.f. (1896) 217, nom. inval.]. — [Themeda gigantea (Cav.) Hack. subvar. mutica Roberty (1960) 91, non Hack. (1889), nom. inval.]. — Lectotype: Née s.n. (MA, no. 475296), designated by Garilleti (1993: 45).

Perobachne secunda J.Presl (1830) 348, t. 48. - Type: Haenke s.n. (holo PR). [Themeda gigantea (Cav.) Hack. forma abbreviata Roberty (1960) 89, nom. inval. - Voucher: Ramos Philipp. PI. 1864 (BO, G, L, SING; PNH lost)]. Anthistiria arundinacea auct. non Roxb.

Schoenus lithospermus auct. non L.

Plants perennial. Culms 1-4 m long, tufted. Nodes glabrous. Ligule c. $1.5 \mathrm{~mm}$ long, margin glabrous. Leaves $30-100 \mathrm{~cm}$ by c. $4.5 \mathrm{~mm}$ wide. Uppermost spatheoles glabrous. Peduncle 1-2 mm long, (sub)glabrous, c. 1/4 as long as the spatheole. Capitules falling as a whole. Involucral spikelets conspicuous, pairs unequally inserted, male; lower glumes linear-lanceolate, $6.5-8.5$ by $0.8-1 \mathrm{~mm}$ wide, acuminate, herbaceous, 11 -nerved (obscured by pubescence), densely brown to golden hirsute; upper glumes 3-nerved. Fertile spikelets 1, 7.3-7.8 mm long (incl. callus), callus c. $1.5 \mathrm{~mm}$ long, hairs brown, $1-1.3 \mathrm{~mm}$ long; lower glumes yellowish brown, apex acute, surface dorsally, marginally, and distally hairy. Awn absent. Anthers 1.5-3.5 $\mathrm{mm}$ long, purple. Pedicel hairy. Pedicelled spikelets 2, male, 7-9 mm long; pedicel appressed hairy; lower glumes apex acuminate, pilose.

Distribution - Moluccas (Halmahera, Fayaul), Philippines (Batanas Isl., Busuanga, Luzon, Mindanao, Mindoro, Negros, Palawan, Panay, Samar (Suluan Isl.)). Surprisingly, Brass 3518 (A, BO, L) from Tulagi Isl., Solomon Isl., growing here and there along the foreshores, belongs here as well (Reeder 1948: 373).

Habitat - Open, exposed places, secondary forest, sea shores; 0-2000 $\mathrm{m}$ altitude.

Uses - PNH 72644 (Conklin \& Rosario) (L) reports 'religious ceremony' in Ifugao, Mt Prov., Luzon; leaves as topical medicine for chest pains (PNH 37923 (Conklin)).

Collector's notes - Stem yellow, up to $2 \mathrm{~m}$. Leaves green above, pale green below. Flowers greenish turning brownish, reddish.

Note - Merrill (1918: 60) thought that Anthistiria gigantea sensu Blanco (1837) would be a misidentification of Saccharum spontaneum L. From Blanco's words, however, it is obvious that he had a Themeda before him, but which one is not clear. Sajise et al. (1974) distinguished 5 taxa in the Philippines. 


\section{Themeda idjenensis Jansen}

Themeda idjenensis Jansen (1952) 482. - Type: Koorders 42922 (holo L sh. 927.345-190; BO1460437).

Themeda arundinacea (Roxb.) A.Camus var. densa Ohwi, nom. ined. Vouchers: Backer 25150, 36946, bb 12218 (Satridihardjo), Bijhouwer 16, Clason-Laarman F116, Koorders 42922 (BO).

Themeda gigantea auct. non Hack.

Themeda gigantea (Cav.) Hack. subsp. avenacea auct. non Hack.

Plants perennial. Culms c. 3 m long, tufted. Nodes glabrous. Ligule 2-3 mm long, margin glabrous. Leaves at least $50 \mathrm{~cm}$ by $4-10 \mathrm{~mm}$ wide. Uppermost spatheoles glabrous. Peduncle 2-10 mm long, extremely short to c. $1 / 3$ times as long as the spatheole, glabrous or white hairy. Capitules long-persistent. Involucral spikelets conspicuous, pairs unequally inserted, male; lower glumes linear-lanceolate to linear, $12-16$ by $1.2-3$ $\mathrm{mm}$, acuminate to aristate, herbaceous, 11-nerved, glabrous; upper glumes 3-nerved. Fertile spikelets 1, 10-11 mm long (incl. callus), callus $1-3 \mathrm{~mm}$ long, hairs white, turning brown, 1.5-5 mm long; lower glumes castaneous, apex acute to truncate, surface dorsally, marginally, and distally puberulous to hairy all over, hairs white. Awn well-developed, 32-58 mm long, column 16-33 mm long (i.s.), straight, puberulous or minutely puberulous $(40 \times$ !) or scaberulous, hairs white (i.s.). Anthers $3.7-7 \mathrm{~mm}$ long, purple i.s. Pedicel glabrous to hairy. Pedicelled spikelets 2, male, 10-16 mm long; lower glumes apex mucronate to aristate, glabrous.

Distribution - E Java (ljen, G. Semongkrong, Tengger), Lesser Sunda Isl. (Bali: Gilimanuk, Klungkung, P. Menjangan).

Habitat - Grass- and shrub jungle, noted by Van der Paardt (\#2, BO) as aggressive and outcompeting other vegetation, on slopes, 10-1500 m altitude.

Collector's notes - Forming gigantic tufts, close together. Flowering culms $3.1 \mathrm{~m}$ tall, brown green (Rappard \# C; L).

Notes - In view of the similarities with e.g. T. arundinacea and T. gigantea the plants are presumably tufted, tall, and have long leaves. The inflorescences are probably also large but collections consist of only parts of them.

The lower glumes of the fertile spikelet appears variable in the colour of the pubescence. Apparently the hairs are snow white when young, and gradually turn brown, but may bleach to white again.

The pedicelled spikelets are sometimes so similar to the involucral ones and inserted so close to them with very brief pedicels, that at first sight they appear to be absent, and that the 6 (!) involucral spikelets are inserted unequally.

The occurrence in Klungkung (bb 12218 (Satridihardjo), BO) is surprising, as it is not so dry there as in the other localities.

\section{Themeda novoguineensis (Reeder) Jansen}

Themeda novoguineensis (Reeder) Jansen (1952) 483. - Themeda gigantea (Cav.) Hack. var. novoguineensis Reeder (1948) 374. - Type: Brass 3710 (holo A; BO, US).

Themeda gigantea auct. non Hack.

Plants perennial. Culms $1.5-3.5 \mathrm{~m}$ long, tufted. Nodes glabrous. Ligule 1-1.2 mm long, margin glabrous. Leaves 38-78 $\mathrm{cm}$ by $2-7 \mathrm{~mm}$. Uppermost spatheoles glabrous. Peduncle 5-8 $\mathrm{mm}$ long, c. $1 / 3$ times as long as the spatheole, white hairy. Capitules long-persistent. Involucral spikelets conspicuous, pairs unequally inserted, male; lower glumes linear-lanceolate, $6.5-10$ by $1-1.5 \mathrm{~mm}$, acuminate, herbaceous, 11-nerved, glabrous or distally with bulbous based bristles; upper glumes 3-nerved. Fertile spikelets 1, 7-9 mm long (incl. callus), callus 1-2.5 mm long, hairs brown, 1.5-3 mm long; lower glumes castaneous, apex truncate, surface puberulous. Awn very short (column more or less straight) to well-developed, imperfect or perfect, 8.5-40 mm long, column 7.5-20 mm long (i.s.) straight, puberulous, hairs white (i.s.). Anthers 1.7-4 mm long, purple i.s. Pedicel glabrous. Pedicelled spikelets 2, male, 6-8.5 $\mathrm{mm}$ long; lower glumes apex acuminate, glabrous.

Distribution - Malesia: Papua New Guinea (Central Prov.).

Habitat - Open grassland in stony riverine plain, Eucalypt savannah, fire resistant. 15-45 m altitude.

Collector's notes - Tall grass. Strong tussocks, 15-20 cm diam. Culms 3-6, erect or arching, up to more than $3.5 \mathrm{~m}$ tall, basal parts distichous. Inflorescence leaning.

Notes - In Papua New Guinea the species is restricted to an area around Port Moresby, Central Prov. Records for Celebes (Henty 1969) and Wetar (Leach \& Dunlop 1993) most likely are misidentifications (T. villosa?).

Sometimes (Heyligers 1277, Schodde 2789; L) the inflorescences appear to be awnless, but it is not clear to me whether this is due to real absence, or that the awns have been shed.

The epithet 'nova-guineensis' was first proposed by Ohwi on labels in BO of March 1944, but it was not published. Reeder did not know about this, but Jansen did! Vouchers for Ohwi are Brass 3589, 3710.

\section{Themeda quadrivalvis (L.) Kuntze}

Themeda quadrivalvis (L.) Kuntze (1891) 794. - Andropogon nutans L. (1771) 303, non L. (1753). - Andropogon quadrivalvis L. (1774) 758, corr. pro L. (1771). - Anthistiria ciliata L.f. (1782 '1781') 113; Retz. (1783) 11; Andersson (1856) 237 ('Retz.'), incl. var. ciliata, nom. superfl. - Themeda ciliata (L.f.) Hack. in Duthie (1888) 89; Hack. (1889) 664, nom. superfl. — [Themeda ciliata (L.f.) Hack. subsp. genuina A.Camus (1920b) 423, nom. inval.]. - [Themeda arguens (L.) Hack. var. ciliata (L.f.) Roberty (1954) 411, comb. inval.: no basion., not in Boissiera 9 (1960)]. — Lectotype: Herb. Linn. 1211.5 (LINN, microfiche IDC; S), designated by Cope (2000: 246). ?Anthistiria barbata auct. non Desf.: Desf. (1792) 294, t. 2, pro descr., illus. - Voucher: ? Jos. Martin in Herb. Thouin s.n. (possibly in G-DEL, MPU, P).

Plants annual (sometimes long-living). Culms $0.1-2$ or more m long, tufted. Nodes glabrous. Ligule 1-3 mm long, margin glabrous to ciliolate. Leaves $15-35 \mathrm{~cm}$ by $2-6 \mathrm{~mm}$. Uppermost spatheoles glabrous. Peduncle $0.5-3 \mathrm{~mm}$ long, extremely short, glabrous. Capitule long-persistent. Involucral spikelets conspicuous, pairs inserted at the same level, sterile or male; lower glumes oblong to lanceolate, $4-7$ by c. $1.5 \mathrm{~mm}$, acute or abruptly obliquely apiculate, herbaceous, 9- or 11-nerved, distally or dorsally with bulbous based bristles; upper glumes 3-nerved. Fertile spikelets 1, 4-6 mm long (incl. callus), callus 0.5-1 mm long, hairs brown, 1.7-2.5 mm long; lower glumes brown to castaneous, apex truncate, surface smooth, puberulous or distally hispidulous. Awn well-developed, perfect, 30$50 \mathrm{~mm}$ long, column 13-21 mm long (i.s.), geniculate, hairs white (i.s.). Anthers 1.3-3 mm long, purple, orange, or yellow i.s. Pedicel glabrous. Pedicelled spikelets 2, sterile or male, 4-7 $\mathrm{mm}$ long, lower glumes apex acuminate to aristate, glabrous. $2 n=$ c. 40 .

Distribution - Sikkim, CE India (East from Madhya Pradesh) to S China; Thailand (Northern: Kamphaeng Phet). In view of the large disjunction in distribution, I suspect introduction also in Malesia: Lesser Sunda Isl. (Sumba, Timor). Reported for Papua New Guinea (Lazarides 1980, but no specimens seen, not in Henty 1969). Sometimes introduced at an early date elsewhere in pasture seed, birdseed, hay, etc. Argentine, N Australia, Cuba, Dominican Republic, Guadeloupe, Fiji, Iraq, Lebanon, Madagascar, Mauritius (Île de France, e.g. Sieber 1821-1823, ? Joseph Martin for Thouin 1788), New Caledonia, Réunion ('Bourbon', e.g. Boivin 1846-1852), Seychelles, Socotra, USA (e.g. California, Florida, Kansas, Louisiana), etc. Reported for Pakistan, but not there (Cope 1982: 316). 
Habitat - Savannah, grasslands (where it can form dense monocultures), roadsides, gardens, sugarcane fields, orchards, fire resistant, from dry $(375 \mathrm{~mm} / \mathrm{a})$ to wet $(4500 \mathrm{~mm} / \mathrm{a})$ areas, favouring soils with medium-textured surfaces (sandy), 200$600 \mathrm{~m}$ altitude.

Uses - Used as a minor fodder grass, in birdseed mixtures (Towne \& Barnard 2000). Regarded as a noxious weed in e.g. Australia, as it can outcompete native species, decrease animal productivity (vigorous and low palatability), and increase fire hazards (Keir \& Vogler 2006).

Collector's notes - Orange red or golden when mature. Panicles reddish, brownish. Spatheoles green, often reddish brown.

Vernacular name - Grader grass, also Habana grass, Kangaroo grass, Oatgrass.

Notes - In some places, e.g. the Levant and possibly elsewhere, confused with $T$. triandra, whereby the delimitation and distribution is uncertain and needs special attention.

Because T. triandra is so common in Malesia, this species is easily overlooked. The differences are few, but clear and appear to be constant. One would be tempted to regard this as a subspecies or variety of it. I have refrained from doing so here, also because of the economic importance of $T$. quadrivalvis.

\section{Themeda triandra Forssk.}

Themeda triandra Forssk. (1775) 178. - Themeda polygama J.F.Gmel. (1791) 149, nom. superfl. — Anthistiria forskalii Kunth (1829) 162 ('foskålii'), nom. superfl. - [Themeda arguens (L.) Hack. subvar. triandra (Forssk.) Roberty (1960) 92, nom. inval.]. — Type: Forsskåhl s.n. (holo C, not found: Hepper \& Friis 1994: 280). - Neotype: to be designated.

Anthistiria imberbis Retz. (1783) 11. - [Anthistiria ciliata L.f. var. $\beta$ Nees (1831) 285, no comb. made]. - Anthesteria imberbis (Retz.) Retz. ex Spreng. 1824; ex Trin. (1832) 321, isonym. - Anthistiria vulgaris Hack. var. imberbis (Retz.) Hack. (1888) 102. - Themeda forskalii Hack. var. imberbis Hack. (\& subvar. typica Hack., nom. inval.) (1889) 661. - Themeda imberbis (Retz.) T.Cooke (1908) 993. - Themeda triandra Forssk. var. imberbis (Retz.) Hack. (1908) 63; Thell. (1912) 74; A.Camus (1920a) 270; (1922) 360, isonyms [incl. subvar. typica (Hack.) A.Camus, nom. inval.]. — [Themeda arguens (L.) Hack. var. imberbis (Retz.) Roberty (1954) 411, comb. inval.: no basion. - Themeda arguens (L.) Hack. subvar. imberbis (Retz.) Roberty (1960) 91, nom. inval.]. - Type: A. Sparrman s.n. via Acharius s.n. in Herb. Retz. (holo LD).

Anthistiria australis R.Br. (1810) 200. - Anthesteria australis (R.Br.) R.Br. ex Spreng. (1824) 291; ex Trin. (1832) 322, isonym. - Themeda australis (R.Br.) Stapf (1919) 420. - Lectotype: R. Brown 6194 (BM, photo in K, $\mathrm{BRI}$; iso $\mathrm{K}$, photo in $\mathrm{BRI}$; $\mathrm{M})$, designated here.

Anthistiria punctata Hochst. ex A.Rich. (1850) 448. - Themeda triandra Forssk. var. punctata (Hochst. exA.Rich.) Stapf (1919) 419. — Lectotype: Schimper I, 73 (P; iso K, L), designated by Chase \& Niles (1962: 397).

[Anthistiria ciliata L.f. var. $\beta$ Nees (1850) 99, nomen, 'subglabra' is the description]. - Anthistiria depauperata Andersson (1856) 243. - Themeda forskalii Hack. subvar. depauperata (Andersson) Hack. (1889) 660. — Lectotype: Cuming 1673 ['1873' is obviously erroneous, as this is Uraria lagopodioides (L.) Desv. ex DC., Leguminosae] (CGE, K, P, W). (Nees'var. $\beta$ is not necessarily the same as that cited sub Anthistiria imberbis (sub Themeda australis)), here designated, location of (holo)lectotype unknown. Anthistiria subglabra Buse (Feb. 1854) 23; (Aug. 1854) 363. - Type: Horner s.n. (holo L sh. 908.83-688).

Apluda barbata Llanos (1858) 497; (1880) 99. - Type: not extant.

Anthistiria vulgaris Hack. (1887) 29, t. 20, nom. inval., auct. non accepit! Themeda forskalii Hack. (1887) 126 ('Forskålii'); (1889) 659, nom. superfl. (incl. p. 660, var. vulgaris Hack., nom. inval.], non Anthistiria forskalii Kunth (1829). - Anthistiria imberbis Retz. var. vulgaris Hack. ex Hook.f. (1896) 212, valid! - [Themeda triandra Forssk. var. vulgaris (Hack.) Domin (1915) 278; A.Camus (1920a) 270, isonym, nom. inval.]. - Themeda arguens (L.) Hack. subvar. vulgaris (Hack.) Roberty (1960) 92, nom. inval.]. - Type: not indicated: "A. ciliata der Autoren, nicht L. fil."

Anthistiria barbata auct. non Desf.

Anthistiria ciliata auct., non L.f.

Themeda quadrivalvis (L.) Kuntze

Plants perennial. Culms $0.3-2 \mathrm{~m}$ long, solitary or tufted. Nodes glabrous. Ligule $0.5-1.5 \mathrm{~mm}$ long, margin glabrous. Leaves
$8-65 \mathrm{~cm}$ by $1.5-4(-10) \mathrm{mm}$ wide. Uppermost spatheoles glabrous or with some bulbous based bristles. Peduncle 1-5 $\mathrm{mm}$ long, extremely short, glabrous or apically white setose. Capitule long-persistent. Involucral spikelets conspicuous, pairs inserted at the same level, sterile or male; lower glumes lanceolate, $7-14(-20)$ by $1-2 \mathrm{~mm}$ wide, acuminate, chartaceous, (9-)11-nerved, glabrous or densely white hirsute; upper glumes 3-nerved. Fertile spikelets 1, (5-)7-8 mm long (incl. callus), callus $0.7-3 \mathrm{~mm}$ long, hairs brown, $3-4.5 \mathrm{~mm}$ long; lower glumes castaneous, apex truncate, distally hispidulous. Awn well-developed, perfect, 30-60 mm long, column 16-30 $\mathrm{mm}$ long (i.s.), straight or geniculate, hairs white (i.s.). Anthers 2-3(-5.25) mm long, purple i.s. or yellow i.s. Pedicel glabrous. Pedicelled spikelets $0-2$, sterile or male, $6-9(-11) \mathrm{mm}$ long. Lower glumes acuminate to aristate, glabrous or rarely distally with some bulbous based bristles. $2 n=$ usually 20 , but many other numbers have been counted, up to 110 .

Distribution - Widespread, S Africa to Australia (incl. Tasmania); Thailand (Northern: Chiang Mai, Chiang Rai, Lampang; Northeastern: Nakhon Phanom; Southwestern: Kanchanaburi, Rachaburi; Central: Phra Nakhon Si Ayutthaya, Saraburi); Malesia: Sumatra (W Coast: Padanglawas), Java (W: only around Cikadal, here and there in Central and East), Madura, Lesser Sunda Isl. (Flores, Sumba, Timor, Wetar), Celebes (Manado, Makassar), Philippines (Batanes Isl., Busuanga Isl., Golo Isl., Luzon, Mindanao, Mindoro, Semirara Isl.), Moluccas (Buru), New Guinea (throughout, fide Henty 1969, but very few specimens seen, e.g. Morobe Prov.).

Habitat - Open grassy areas, roadsides, e.g. with Imperata, shrubby jungle, in deciduous dipterocarp-oak forest, Eucalypt and Casuarina savannahs, often on less fertile soil with a strong dry monsoon, locally dominant, fire resistant, 0-2200 m altitude.

Collector's notes - Densely tufted, stramineous, reddish brown. Culms erect, yellowish-green or -brown, pale purple, waxy underneath the nodes. Leaves glaucous or dull green above, pale green below. Inflorescences nodding. Spathas glaucous, often with purple base. 'Flowers' brown, reddish. Involucral spikelets glaucous, pale green, apex sometimes purplish. Awns maroon, glossy black.

Uses - In Java only when young regarded as a moderate fodder, yet esteemed in Australia and South Africa. Grain edible. Not very suitable for paper making. Because of the various colours of the leaves, some cultivars are used as ornamentals, from where they may escape.

Vernacular names - Kangaroo grass, Red oat grass, Rooigras.

Notes - Hackel created an impressive confusion by the use of the epithet 'forskalii' with 10 varieties and 7 subvarieties. Camus (1920a) recognised even 13 and 7 , respectively. These are mainly based on pubescence. The involucral spikelets may bear bulbous based bristles in the upper part, but a special status for the bristled ('vulgaris') and non-bristled ('imberbis') forms does not seem warranted ('idle', Bor 1960: 254; 'of little value', Clayton \& Renvoize 1982: 831) as both seem to occur over the whole range.

The pedicelled spikelets are often absent, even in the same specimen. Clayton \& Renvoize (1982) twice depict only a single pedicelled spikelet. This I have never seen.

\section{Themeda villosa (Poir.) A.Camus}

Themeda villosa (Poir.) A.Camus (1922) 364 [incl. var. typica A.Camus, nom. inval.]; T.Durand \& B.D.Jacks. ex Ridl. (1925) 212, isonym. - Anthistiria villosa Poir. (1799) 434, t. 841, f. 3; (1810) 396. - Androscepia gigantea (Cav.) Brongn. var. armata Andersson (1856) 248. - Themeda gigantea (Cav.) Hack. subsp. \& var. villosa (Poir.) Hack. (1889) 675 [incl. subvar. typica Hack., p. 676, nom. inval.]. - Anthistiria gigantea Cav. subsp. villosa (Poir.) Hack. ex Hook.f. (1896) 217. - Anthistiria gigantea Cav. var. 
villosa (Poir.) Hack. ex Ridl. (1907) 169. - [Themeda gigantea (Cav.) Hack. subvar. villosa (Poir.) Roberty (1960) 92, nom. inval.]. - Lectotype: Commerson s.n. in Herb. Lamarck, P, microfiche IDC 6207, fiche 686/8; iso ?Fl; L sh. 980.83-81), designated here.

Heterelytron scabrum Jungh. (1840) 295. - Anthesteria mutica Hassk. (1843) 117, nom. superfl. — Anthistiria junghuhniana Nees (1850) 99 ('in sched.': incorr.); ex Andersson (1856) 233, nom. superfl. - Anthistiria ciliata L.f. var. junghuhniana Buse ex Miq. (1857) 504. - Themeda gigantea (Cav.) Hack. subvar. mutica Hack. (1889) 676. - Type: Junghuhn s.n. "Pertotam insulam (Java) locis apricis, siccis usque ad 2000 pedem altitudinem. Nomen: manja". (not found in L).

Androscepia gigantea (Cav.) Brongn. var. sundaica Buse (Feb. 1854) 24; (Aug. 1854) 364. - Themeda villosa (Poir.) A.Camus var. sundaica (Buse) A.Camus (1922) 364. - Lectotype: Junghuhn s.n. 'Tjibogo' (L sh. 908.83271; iso L sh. -281, -296), designated here.

Themeda gigantea auct. non Hack.

\section{a. var. villosa}

Plants perennial. Culms 1.5-3.5 m long, tufted. Nodes glabrous. Ligule c. $1.5 \mathrm{~mm}$ long, margin glabrous to ciliolate. Leaves $100-250 \mathrm{~cm}$ by $6.5-20 \mathrm{~mm}$. Uppermost spatheoles glabrous. Peduncle $8-15 \mathrm{~mm}$ long, usually c. $1 / 2$ times as long as the spatheole, rarely less, white hairy. Capitule long-persistent. Involucral spikelets conspicuous, pairs unequally inserted, male; lower glumes linear-lanceolate, (6-)8-21 by $1-2 \mathrm{~mm}$, acuminate, herbaceous, 11-nerved, scaberulous or dorsally with some long hairs; upper glumes 3-nerved. Fertile spikelets 2-3 (rarely 1 or 4), 9.5-12.5 mm long (incl. callus); callus $1.5-3 \mathrm{~mm}$ long, pilose, hairs brown, 1.5-2 mm long; lower glumes castaneous or brown or yellowish, apex truncate, hairs castaneous. Awn (careful: sometimes early deciduous!) or very short (column more or less straight) or well-developed (exceptionally well-developed with a contorted column), imperfect to perfect, absent or very short, column more or less straight, usually imperfect, rarely well-developed and column contorted, $0(-32)$ $\mathrm{mm}$ long, column 0-14 mm long (i.s.), scaberulous, hairs white or rufous (i.s.). Anthers 2.5-3.2(-7) mm long, purple i.s. Pedicel appressed hairy. Pedicelled spikelets 3-4, male, 11-19 $\mathrm{mm}$ long; lower glumes apex acuminate, glabrous to minutely puberulous. $2 \mathrm{n}=20,32$.

Distribution - NE India (E from Bihar), Nepal to Tibet and $S$ China (E to Hubei), Nicobars, Thailand (Northern: Chiang Mai; Southwestern: Rachaburi; Peninsular: Nakhon Si Thammarat, Narathiwat, Songkhla, Trang); Malesia: Malay Peninsula (widespread), Singapore, Sumatra (Aceh, E-, W Coast, Lampong, Palembang, Riau), Lingga, Bangka, Java (mainly in the West), Madura, Borneo (widespread, rare), Celebes (widespread, rare), Philippines (Cebu, Mindanao, Negros, Palawan, rare), Lesser Sunda Isl. (Bali, Flores, Komodo, Sumba, Sumbawa, Timor), Moluccas (Buru), Papua New Guinea (Vogelkop: Kaimana). Introduced elsewhere as an ornamental, e.g. Hawaii, Sri Lanka.

Habitat - Sunny roadsides, sandbanks, river banks, grass jungles, abandoned fields, sometimes dominant, Eucalypt savannah, 0-1700 m altitude. Lörzing $(6630, \mathrm{BO})$ noted that it did not occur on peat but was plentiful on volcanic rock, whereby one might tell the geological formation from its occurrence.

Vernacular name - Silky kangaroo grass.

Uses - Young shoots produce a sweet vegetable; used against cough; young marrow used to prevent infection of fresh ear holes; internodes formerly used as shafts for dip pens; leaves for roofing; clumps used as living hedges. Ash used as fertiliser. Occasionally planted as an ornamental, but because it is fertile, it may spread and become weedy.

Collector's notes - Tufts $2-3.5 \mathrm{~m}$ tall, nodding. Culms with c. 15 nodes $30 \mathrm{~cm}$ apart, yellow green, mauve. Leaves to $1.8 \mathrm{~m}$ long, glaucous, with very pale midrib. Inflorescences mauve. Lemma (i.e. involucre) green. Flowers brown. Stigmas purple.
Notes - Usually the fertile spikelets are quite muticous (mutica, sundaica), but occasionally some or all may be awned, with awns as long as $30 \mathrm{~mm}$ (e.g. Backer 17436; BO, L) (armata, villosa) sometimes even within the same capitules. A taxonomic distinction therefore seems impossible.

Rarely some lower glumes have long hairs as in T. arundinacea and $T$. villosa var. polyantha, but for other features the collections are best placed here.

The use by Gilliland (1971) was based on mixed collections. The illustration depicts $T$. villosa var. caudata.

Note the disjunction between W-, C Malesia and New Guinea.

\section{b. var. caudata (Nees) Veldk., comb. nov.}

Anthistiria caudata Nees in Hook. \& Arn., Bot. Beechey Voy. (1838) 245 - Themeda gigantea (Cav.) Hack. subsp. caudata (Nees) Hack. (1889) 676. - Anthistiria gigantea Cav. subsp. caudata (Nees) Hack. ex Hook.f. (1896) 217. - Themeda caudata (Nees) [Hack. ex T.Durand \& B.D.Jacks. (1906) 424, in syn.] A.Camus (1922) 364; Honda (1926) 108, isonym. - [Themeda gigantea (Cav.) Hack. var. caudata (Nees) Keng (1957) 149, 247; (1959) 845, t. 792, comb. inval. (no basion.)]. - [Themeda gigantea (Cav.) Hack. subvar. caudata (Nees) Roberty (1960) 90, nom. inval.]. - Lectotype: Vachell 46, p.p. in Herb. Lindley (CGE, 16260, marked 'A'; iso, 16261, marked 'B'), designated here.

Themeda villosa auct. non A.Camus.

Themeda gigantea auct. non Hack.

Plants perennial. Culms 1-6 m long, tufted. Nodes glabrous or pilose. Ligule $0.7-2 \mathrm{~mm}$ long, margin ciliolate to setose, sometimes fimbriate. Leaves $20-150 \mathrm{~cm}$ by $2.5-16 \mathrm{~mm}$. Uppermost spatheoles glabrous. Peduncle 11-35 mm long, c. $1 / 3$ to c. $1 / 2$ times as long as the spatheole, glabrous or white hairy. Capitule long-persistent. Involucral spikelets conspicuous, unequally inserted, male; lower glumes linear-lanceolate to linear, 11-15(-21) by $1.5-2 \mathrm{~mm}$, acuminate, herbaceous, 11-nerved, glabrous, scaberulous, minutely puberulous, or dorsally with some long hairs; upper glumes 3-nerved. Fertile spikelets $2-3,6-11.5 \mathrm{~mm}$ long (incl. callus); callus $1-2(-3)$ $\mathrm{mm}$ long, pilose, hairs white, gold, or brown, 1-2 mm long; lower glumes yellowish, apex obtuse to truncate, surface hairy all over, spikelets hairs white, golden, or castaneous. Awn well-developed (column contorted), perfect, 23-60 mm long, column 12-37 mm long (i.s.), straight, puberulous, hairs white (i.s.). Anthers 2-6(-7.5) mm long, purple or orange i.s. Pedicel glabrous or hairy. Pedicelled spikelets 3-4, male, 8.5-15(-19) $\mathrm{mm}$ long, lower glumes apex acuminate to caudate, glabrous or sparsely pilose.

Distribution - Sikkim, Bhutan, N India (E from Madhya Pradesh) to E China (E to Zhejiang), Taiwan, to New Caledonia, Thailand: Northern: Chiang Mai; Northeastern: Loei; Southwestern: Kanchanaburi; Peninsular: Pattani; Malesia: Malay Peninsula (Kelantan, Pahang), Singapore, Sumatra (E Coast, Riau), Bangka, Borneo (S. Kalimantan, Sabah), Celebes (Central: Singkalong; Southeast: Kendari).

Habitat - Roadsides, grassy slopes, locally dominant on better soils, 10-1950 m altitude.

Collector's notes - Very tall grass, 1.5-6 m tall, tufted. Inflorescences secund, pendulous, green. Awns brown. Anthers yellow.

Note - This is a puzzling taxon rather rare in the herbarium, but widely distributed. The floral dimensions are very variable. The type specimens have exceptional larger parts. It would seem that the variety is merely the awned form of $T$. villosa s.str., but the overall aspect of the spikelets, hard to bring under words, is different. 
c. var. polyantha (Brongn. ex Buse) Veldk., comb. nov.

[Androscepia gigantea (Cav.) Brongn. var. $\beta$ Brongn. (1831) 78]. - Androscepia gigantea (Cav.) Brongn. var. polyantha Brongn. ex Buse in Miq., PI. Jungh., preprint (Feb. 1854) 24; 3 (Aug. 1854) 364. - Themeda gigantea (Cav.) Hack. var. amboinensis Hack. (1889) 673, nom. superfl. — [Themeda gigantea (Cav.) Hack. subvar. amboinensis (Hack.) Roberty (1960) 89, nom. inval.]. - Syntypes: Brongniart cited Ambon and Java (d'Urville in Herb. de Ventenat; G), n.v.

Themeda gigantea (Cav.) Hack. subsp. \& var. intermedia Hack. (1889) 675 - Themeda intermedia (Hack.) [Hack. ex T.Durand \& B.D.Jacks. (1906) 424, in syn.] Bor (1938) 96; T.Durand \& B.D.Jacks. ex Jansen (1952) 481, isonym; Bor (160) 251 (pro hybrid.). - [Themeda gigantea (Cav.) Hack. subvar. intermedia (Hack.) Roberty (1960) 91, nom. inval.]. - Type: Hookerf. \& T. Thomson s.n. 'Androscepia no. 4' (holo W, fragm. in L; G, K, photo in BRI; L sh. 908.83-723, 957.58-303).

Themeda gigantea (Cav.) Hack. var. dubia Hack. (1889) 675. — [Themeda gigantea (Cav.) Hack. subvar. dubia (Hack.) Roberty (1960) 90, nom. inval.]. - Type: Cuming 1609 (holo W; G, L sh. 908.83-277 (sub Cuming 6019), S (sub Cuming 1437)).

Themeda gigantea auct. non Hack.

Plants perennial. Culms $2-5 \mathrm{~m}$ long, tufted. Nodes glabrous. Ligule $0.5-1.5 \mathrm{~mm}$ long, margin glabrous to ciliolate. Leaves up to $100 \mathrm{~cm}$ by $3-15 \mathrm{~mm}$. Uppermost spatheoles glabrous. Peduncle 10-14 mm long, c. $1 / 3$ to c. $1 / 2$ times as long as the spatheole, white to golden hairy. Capitules long-persistent. Involucral spikelets conspicuous, pairs unequally inserted, sterile or male; lower glumes linear-lanceolate, $8-15$ by $1-1.5$ $\mathrm{mm}$, acuminate, herbaceous, 11-nerved, more or less densely brown to golden hirsute (hairs sometimes bulbous based); upper glumes 3-nerved. Fertile spikelets 2-3, 8-11.5 mm long (incl. callus), callus $1.5-2.5 \mathrm{~mm}$ long, hairs brown, c. $2 \mathrm{~mm}$ long; lower glumes castaneous, apex truncate, surface laterally hairy to hairy all over, hairs castaneous. Awn absent to short, imperfect, $0-30 \mathrm{~mm}$ long, column straight or geniculate, puberulous, hairs rufous (i.s.). Anthers $3-6 \mathrm{~mm}$ long, purple (i.s.). Pedicel appressed hairy. Pedicelled spikelets 3-4, male, 11-14 $\mathrm{mm}$ long, lower glumes apex acuminate to aristate, minutely puberulous and pilose. $2 n=20$.

Distribution - NE India (E from Assam) to N Queensland (Moa Isl., Torres Str.), Solomon Isl., Vanuatu; Thailand: Northern (Chiang Mai), Malesia: Sumatra (Riau), Malay Peninsula (Pahang), Lesser Sunda Isl. (Alor, Flores, Sumbawa, Timor, Wetar), Borneo (Pontianak, Sabah, Sarawak), N Celebes, Talaud Isl., Philippines (Bohol, Mindanao, Palawan), Moluccas (Ambon, Halmahera), New Guinea (widespread).

Habitat - (Eucalypt) savannah, gravel bars in river, grass jungles, fire resistant, 0-1450 m altitude.

Uses - Sometimes grown as an ornamental.

Collector's notes - Culms 3-3.5 m long. Internodes $35 \mathrm{~cm}$ long. Leaf sheath $13 \mathrm{~cm}$ long; blade $1 \mathrm{~m}$ long. Lemma (= lower glumes of involucre) with orange hairs. Palea (? = upper glumes of involucre) glabrous. Anthers orange, pendulous. Stigma purple, pilose.

Notes - Thought by Bor to be a hybrid between T. arundinacea and T. villosa in which the awn is missing (Bor 1960: 251), but many specimens, incl. the type have at least some awns up to $30 \mathrm{~mm}$ long. Perhaps the notion that this would be a hybrid was possibly prompted by its morphologically intermediate position. I have found no reports on hybridisations in Themeda. Noltie (2000: 822) has suggested that it might be a form of $T$. subsericans, here regarded as a synonym of $T$. arundinacea.

The difference with var. villosa is slight, but apparently constant.

\section{NOTES}

\section{Themeda hookeri (Griseb.) A.Camus}

Themeda hookeri (Griseb.) A.Camus (1920b) 425. - Anthistiria hookeri Griseb. (1868) 91. — Lectotype: Hooker f., Sikkim, Androscepia 2 (GOET 9981; iso in K, L), Sikkim, Choongtang, designated here. Anthistiria gigantea auct. non Cav.

Anthistiria gigantea (Cav.) Hack. subsp. caudata auct. non. Hack. Themeda caudata auct. non A.Camus.

Themeda gigantea auct. non Hack.

Plants perennial. Culms 0.2-0.6 m long, tufted. Nodes glabrous. Ligule $0.5-1 \mathrm{~mm}$ long, glabrous to setose. Leaves $3-13 \mathrm{~cm}$ by 2-6 mm. Uppermost spatheoles glabrous. Peduncle 7-14 mm long, c. 1/2 times as long as the spatheole, glabrous or white hairy. Involucre persistent. Involucral spikelets conspicuous, pairs unequally inserted, with 2 glumes and 1 lemma, male; lower glumes linear-lanceolate to linear, $9-14$ by $1-2 \mathrm{~mm}$, acuminate, herbaceous, 11-nerved, glabrous; upper glumes 3-nerved. Fertile spikelets 2, 4.5-8.5 mm long (incl. callus), callus 1-1.5 mm long, hairs white, 1-2 mm long; lower glumes yellowish brown, apex obtuse, surface smooth and distally hispidulous to white hairy all over. Awn perfect, 20-40 mm long, column 12-20 mm long (i.s.), straight, puberulous, hairs white (i.s.). Anthers 3-4 mm long, purple or orange. Pedicelled spikelets 3, male, 8-12 mm long; pedicel glabrous to laterally appressed hairy; lower glumes apex acuminate, glabrous.

Distribution - Sikkim, Nepal, NE India (Khasia. Not in Shukla 1996), Thailand (Northern: Chiang Mai), S China (Guizhou, Sichuan, Xizang, Yunnan).

Ecology - Mountain slopes, rocky places, fire prone grassy area in mixed primary evergreen hardwood and pine forest; 1100-3400 $m$ altitude.

Collector's notes - Culms tufted, dull violet reddish. Blades green on both sides. Glumes green to violet reddish.

Notes - The collection from Chiang Mai (Maxwell 92-568, CMU, $L$ ) is a new record for Thailand.

Two forms apparently appear to be present differing mainly in the pubescence of some inflorescence parts, which have been merged above:

-. Peduncle of raceme glabrous. Fertile spikelets 4.5-6.5 mm long (incl. callus), callus hairs c. $1 \mathrm{~mm}$ long. Pedicelled spikelets pedicel glabrous ......... T. hookeri - Thailand

-. Peduncle of raceme white hairy. Fertile spikelets c. $8.5 \mathrm{~mm}$ long (incl. callus), callus hairs c. $2 \mathrm{~mm}$ long. Pedicelled spikelets pedicel appressed hairy ....... T. hookeri-Sikkim

\section{Themeda polycephala Veldk., sp. nov.}

Type. Poilane 28428 (holo L; E, K, P).

Plants perennial. Culms c. $2 \mathrm{~m}$ long, solitary. Nodes glabrous. Ligule 1-1.7 mm long, margin ciliolate. Leaves $42-65 \mathrm{~cm}$ by 7-10 mm. Uppermost spatheoles glabrous. Peduncle 7-10 $\mathrm{mm}$ long, c. 1/2 times as long as the spatheole, white hairy. Capitules bi- or ternate, reflexed, long-persistent. Involucral spikelets conspicuous, pairs unequally inserted, male; lower glumes linear-lanceolate, $6-9$ by $1-1.4 \mathrm{~mm}$, acutish, herbaceous, 9-nerved, glabrous, keels distally setose; upper glumes 3-nerved. Fertile spikelets 2, 6.5-7 mm long (incl. callus), callus 1.5-2 mm long, pilose, hairs whitish, c. $2 \mathrm{~mm}$ long; lower glumes yellowish, apex truncate, glabrous, keels distally setose. Awn well-developed, perfect, 35-42 mm long, column 21-23 $\mathrm{mm}$ long (i.s.), geniculate, setulose, hairs white (i.s.). Anthers 2-3 mm long, purple i.s. Pedicel laterally setose. Pedicelled spikelets 4, male, 6.5-7 mm long, lower glumes apex acute to aristulate (arista up to $2 \mathrm{~mm}$ long), glabrous, keels distally setulose. 
Distribution - Only known from the type: Laos, Champassak Prov., $55 \mathrm{~km}$ from Pakson(g), at Tateng, Plateau des Boloven(s), 13 Nov. 1938. tude.

Habitat - Not recorded. The plateau is at 1000-1200 m alti-

Note - This is a most curious species, especially because of the paired to ternate, reflexed spikelets at the end of the peduncle, unique in the genus. Also, the distally setose keels of the glumes have not been seen elsewhere.

Acknowledgements The late Dr. H. Scholz kindly checked some collections in B. Mr. F. Verloove did so in BR. Kew kindly sent some crucial material to disentangle T. caudata. The keepers and directors of A, ANDA, BIOT, BISH, BO, BRUN, CGE, EBL, L, MEL, PTBG, S, SAN, SAR, SING, SNP, U, and WAG (the latter two now in $L$ ) are very much thanked for making available their collections. The librarians of $L$ went out of their way to trace obscure publications. Not everything is on the internet as some claim!

\section{REFERENCES}

Andersson NJ. 1856. Monographiae andropogonearum. I. Anthistirieae. Nova Acta Regiae Societatis Scientiarum Upsaliensis III, 2: 229-255, t. 3. Backer CA. 1928. Handboek voor de flora van Java 2: 106-110. Ruygrock \& Co. Batavia.

Backer CA. 1936. Verklarend woordenboek van wetenschappelijke plantennamen: 31, 435. Noordhoff, Groningen.

Beauvois AMFJ Palisot de. 1812. Essai d'une nouvelle agrostographie: 128-129, 151, 157, excl. t. 23, f. 1. Palisot de Beauvois, Paris.

Bentham G, Hooker JD. 1883. Genera plantarum 3: 1136-1137. Reeve \& Co, Williams \& Norgate, London.

Blanco M. 1837. Flora de Filipinas: 49-51. Lopez, Manila.

Bor NL. 1938. A list of the grasses of Assam. Indian Forest Records (new series), Botany 1, 3: 95-97, f.

Bor NL. 1960. The grasses of Burma, Ceylon, India and Pakistan (excluding Bambuseae). International series of monographs on pure and applied biology. Division botany 1: 248-255.

Bor NL. 1970. Gramineae. In: Rechinger KH (ed), Flora Iranica 70/30: 546547. Akademische Druck- und Verlagsanstalt, Graz.

Brongniart A. 1831 '1829'. In: Duperrey L, Voyage autour du monde, Botanique, Phanérogamie 2: 77-78. Bertrand, Paris.

Brown R. 1810. Prodromus florae Novae Hollandiae 1: 200. Johnson \& Co., London.

Buse LH. 1854. Gramineae. In: Miquel FAW, Plantae junghuhnianae 3 (Feb. 1854) preprint: 23-24; (Aug. 1854) 363-364. Sythoff, Leiden.

Camus A. 1920a. Note sur le genre Themeda Forsk. (Graminées). Bulletin du Muséum National d'Histoire Naturelle 26: 266-273.

Camus A. 1920b. Note sur la synonymie et répartition géographique de quelques Themeda. Bulletin du Muséum National d'Histoire Naturelle 26: 423-428.

Camus A. 1922. Themeda. In: Lecomte MH, Flore générale de l'Indo-Chine 7: 356-365. Masson \& Cie, Paris.

Cavanilles AJ. 1799. Icones et descriptiones plantarum 5: 36-37, t. 458, 459. Typographia Regia, Madrid.

Chase A, Niles CD. 1962. Index to grass species 3: 397. Hall \& Co., Boston (Mass.).

Clayton WD, Renvoize SA. 1982. Flora of tropical East Africa. Gramineae 3: 828-831, t. 192. Balkema, Rotterdam.

Clayton WD, Renvoize SA. 1986. Genera graminum. Kew Bulletin, Additional Series 13: 354-361.

Clayton WD, Vorontsova MS, Harman KT, et al. 2014-onwards. GrassBase - The online world grass flora. (acc. 3 April 2014) http://www.kew.org/data/ grasses-db.html.

Cooke T. 1908. The flora of the presidency of Bombay 2: 993. Taylor \& Francis, London.

Cope TA. 1982. Poaceae. In: Nasir E, Ali SI, Flora of Pakistan 143: 315-317. Department of Botany, University of Karachi, Pakistan; National Herbarium, Pakistan Agricultural Research Council, Islamabad, Pakistan.

Cope TA. 2000. In: Cafferty S, et al., Typification of Linnaean plant names in the Poaceae. Taxon 49: 246.

Desfontaines RL. 1792. Mémoire sur le genre Anthistiria. Journal de Physique, de Chimie, d'Histoire Naturelle 40: 292-295, t. 1, 2.

Domin K. 1915. Beiträge zur Flora und Pflanzengeographie Australiens. Bibliotheca Botanica 85, 1: 272-280.

Durand T, Jackson BD. 1906. Index Kewensis, Supplement 1: 31, 424. Castaigne, Brussels.
Duthie JF. 1888. The fodder grasses of northern India: 42-43, 89 (errata). Thomason Civil Engineering College Press, Roorkee.

Endlicher S. 1836. Genera plantarum: 107-108. Beck, Wien.

Forsskåhl P. 1775. Flora Aegyptiaco-Arabica: cxxiii, 178-179. Möller, Copenhagen.

Garilleti R. 1993. Herbarium cavanillesianum. Fontqueria 38: 45.

Gilliland HB. 1971. A revised flora of Malaya 3. Grasses of Malaya: 299-303, t. 65. Lim Bian Han, Singapore.

Gmelin JF. 1791. Systema naturae 2: 149. Beer, Leipzig

Grisebach A. 1868. Ueber die Gramineen Hochasiens, Nachrichten von der Königlichen Gesellschaft der Wissenschaften und der Georg-AugustsUniversität 3: 91.

Hackel E. 1887. Gramineae. In: Engler A, Prantl K, Die natürlichen Pflanzenfamilien 2, 2: 29, 126, t. 20. Engelmann, Leipzig.

Hackel E. 1888. In: Wawra W, Itinera principum S. Coburgi 2: 102. Gerold's Son, Wien. n.v.

Hackel E. 1889. Themeda. In: De Candolle ALPP, De Candolle ACP, Monographiae phanerogamarum, etc. 6: 653-678. Masson. Paris.

Hackel E. 1908. List of grasses collected at Bulawayo by M.D.W. Jeffreys. Proceedings of the Rhodesia Scientific Association 7: 63.

Hasskarl JK. 1843. Adnotationes de plantis quibusdam javanicis nonnullisque japonicis, haud rite cognitis, e Catalogo Horti bogoriensis excerptae. Accedunt nonnullae novae species. Tijdschrift voor Natuurlijke Geschiedenis en Physiologie 10: 117-118.

Henrard JT. 1941. Notes on the nomenclature of some grasses II. Blumea 4: 522 .

Henty EE. 1969. A manual of the grasses of New Guinea. Botany Bulletin, Lae 1: 183-185, t. 69.

Hepper FN, Friis I. 1994. The plants of Pehr Forsskal's 'Flora aegyptiaco-arabica': 280. Royal Botanic Gardens, Kew \& Botanical Museum, Copenhagen. Honda M. 1926. Revisio graminum japoniae. IX. Botanical Magazine (Tokyo) 40: $107-108$.

Hooker JD. 1896. The flora of British India 7: 210-217. Reeve \& Co., Brook nr. Ashford.

Houttuyn M. 1782. Natuurlijke historie II, 13: 334-335, t. 982, f. 1. Houttuyn, Amsterdam.

Jansen P. 1952. Notes on Malaysian grasses II. Acta botanica neerlandica 1: 479-483

Jarvis C. 2007 . Order out of chaos: 875 . Linnean Society in association with the Natural History Museum, London.

Junghuhn F. 1840. Genera et species plantarum florae javanicae. Tijdschrift voor Natuurlijke Geschiedenis en Physiologie 7: 294-298.

Keir AF, Vogler WD. 2006. A review of current knowledge of the weedy species Themeda quadrivalvis (grader grass). Tropical Grasslands 40: 193-201.

Kellogg EA, Watson L. 1993. Phylogenetic studies of a large data set. I. Bambusoideae, Andropogonodae, and Pooideae (Gramineae). Botanical Review 59: 274-343.

Keng YL. 1957. Claves generum et specierum graminearum primarum sinicarum: 149, 247. Science Press, Peking.

Keng YL. 1959. Flora illustrata plantarum primarum sinicarum. Gramineae: 845, t. 792. Science Press, Peking

Kunth CS. 1829. Révision des graminées 1: 162. Gide fils, Paris

Kuntze O. 1891. Revisio generum plantarum 2: 794. Felix, Leipzig, etc.

Lazarides M. 1980. The tropical grasses of Southeast Asia (excluding bamboos). Phanerogamarum Monographiae 12: 76-78.

Leach GJ, Dunlop CR. 1993. The vegetation and floristics of Kali Kuning Project Area, Wetar Island, Indonesia: t. 1. Northern Territory Herbarium, Conservation Commission of the Northern Territory, Palmerston.

Linnaeus C. 1753. Species plantarum: 1045. Salvius, Stockholm.

Linnaeus C. 1762. Species plantarum, ed. 2, 1: 65, 117. Salvius, Stockholm. Linnaeus C. 1771. Mantissa plantarum altera: 303-304. Salvius, Stockholm. Linnaeus C. 1774. Systema vegetabilium, ed. 13 ('Murray'): 758. Dietrich, Göttingen, Gotha.

Linnaeus Jr C. 1782 '1781'. Supplementum plantarum: 113. Orphanotropheus, Braunschweig

Llanos A. 1858. Nuevo apéndice ó suplemento a la Flora de Filipinas del P. Fr. Manual Blanco. Memorias, Real Academia de Ciencias Exactas, Fisicas y Naturales de Madrid 4: 497.

Llanos A. 1880. In: Fernandez-Villar C, Novissima appendix ad floram Philippinarum: 99. Plana y C.a., Manila.

McNeill J, et al. 2012. International Code of Nomenclature for algae, fungi, and plants (Melbourne Code). Regnum Vegetabile 154.

Merrill ED. 1917. An interpretation of Rumphius' herbarium amboinense. Bureau of Agriculture and Natural Resources, Bureau of Science, Publication 9: 89-90.

Merrill ED. 1918. Species blancoanae: 60. Bureau of Printing, Manila.

Miquel FAW. 1857. Flora van Nederlandsch Indië 3: 504-506. Van der Post, Amsterdam; Van der Post Jr., Utrecht; Fleischer, Leipzig. 
Munro W. 1862. On the identification of the grasses in Linnaeus's herbarium, now in the possession of the Linnean Society of London. Journal of the Proceedings of the Linnean Society, Botany 6: 47.

Naezén DE. 1779. Nova graminum genera: 35, 37, illus. Edman, Upsala.

Naezén DE. 1790. Nova graminum genera in C. Linnaeus (JCD Schreber, ed.). Amoenitates academicae 10, App.: 38, t. 1. Palm, Erlangen.

Nees ab Esenbeck CG. 1831. Plantae ecklonianae. Linnaea 7: 285-286.

Nees ab Esenbeck CG. 1838. Gramineae. In: Hooker WJ, Walker Arnott GA, The botany of Captain Beechey's voyage: 245. Bohn, London.

Nees ab Esenbeck CG. 1850. Gramineae herbarii lindleyani. Hooker's Journal of Botany and Kew Garden Miscellany 2: 99.

Noltie HJ. 2000. Flora of Bhutan 3, 2: 820-822. Royal Botanic Gardens Edinburgh, Edinburgh.

Pilger R. 1940. Gramineae III, Unterfamilie Panicoideae. In: Engler A, Prantl K, Die natürlichen Pflanzenfamilien, ed. 2, 14e: 178-179, t. 95. Engelmann, Leipzig.

Poiret LJM. 1799. In: Lamarck JBAP Monnet de, Tableau encyclopédique et méthodique, botanique 3: 434 , t. 841 , f. 3. Panckoucke, Paris

Poiret LJM. 1810. Encyclopédie méthodique. Botanique, Supplement 1: $394-$ 396. Panckoucke, Paris; Plomteux, Liège.

Presl CB. 1833. Repertorium botanicae systematicae 1: 304-306. Haase, Prague.

Presl JS. 1830. Anthistiria, Perobachne. In: PresI CB, Reliquiae haenkeanae 1: 347-349, t. 48. Calve, Prague.

Reeder JR. 1948. The Gramineae-Panicoideae of New Guinea. Journal of the Arnold Arboretum 29: 371-374.

Retzius AJ. 1783. Observationes botanicae 3: 11. Crusius, Leipzig.

Richard A. 1850. Tentamen florae abyssinicae 2: 448-450. Bertrand, Paris. Ridley HN. 1893. On the flora of the eastern coast of the Malay Peninsula. Transactions of the Linnean Society of London, Botany. 3: 401.

Ridley HN. 1907. Materials for a flora of the Malayan Peninsula 3: 168-170. Methodist's Printing House, Singapore.

Ridley HN. 1925. The flora of the Malay Peninsula 5: 211-212. Reeve \& Co., London.

Roberty G. 1954. Petite flore de l'Ouest Africain: 411. Larose, Paris.

Roberty G. 1960. Monographie systématique des Andropogonées du globe. Boissiera 9: 86-99. (with Iseilema, Germainia, Pleiadelphia = Elymandra as sections).

Roemer JJ, Schultes JA. 1817. Systema vegetabilium 2: 810. Cotta, Stuttgart. Roxburgh W. 1814. Hortus bengalensis: 6. Mission Press, Serampore.

Roxburgh W. 1820. Flora indica 1: 251-257. Thacker \& Co., Calcutta; Parbury, Allen \& Co., London.

Rumphius EG. 1750. Herbarium Amboinense 6: 15-16, t. 6, f. 1, 2. Changuion, etc., The Hague, etc.

Sajise PE, Orlido NM, Castillo LC, et al. 1974. Studies on the genus Themeda. Kalikasan 3: 71-82.
Schultes JA. 1824. Mantissa 2: 457-458. Cotta, Stuttgardt.

Shukla U. 1996. Grasses of North-Eastern India: 138-142. Scientific Publishers, Jodhpur.

Skendzic EM, Columbus JT, Cerros-Tlatilpa R. 2007. Phylogenetics of Andropogoneae (Poaceae: Panicoideae) based on nuclear ribosomal internal transcribed spacer and chloroplast trn-L-F sequences. Aliso 23: 530-544.

Sprengel K. 1817. Anleitung zur Kenntnis der Gewächse, ed. 2, 1: 179. Kummel, Halle.

Sprengel K. 1824. Systema vegetabilium 1: 290-291. Dieterich, Göttingen.

Stafleu FA, Cowan RS. 1981. Taxonomic literature, ed. 2, 3. Regnum Vegetabile 105: 686 .

Stapf O. 1919. Gramineae. In: Prain D, Flora tropical Africa 9: 419-420. Reeve \& Co., London.

Steudel EG. 1854a (June). Gramineae. In: Zollinger H, Systematisches Verzeichnis 1: 58. Kiesling, Zürich.

Steudel EG. 1854b (July). Synopsis plantarum glumacearum 1: 399-402. Metzler, Stuttgart.

Thellung A. 1912. La flore adventice de Montpellier. Mitteilungen aus dem Botanischen Museum der Universitat Zürich, preprint of Mémoires de la Société Nationale des Sciences Naturelles de Cherbourg 38: 74-75.

Thunberg CP. 1784a. In: Murray JA, Systema vegetabilium, ed. 14: 903. Dieterich, Göttingen.

Thunberg CP. 1784b. Flora japonica: 40-41. Müller, Leipzig.

Thwaites GHK. 1864. Enumeratio plantarum zeylaniae: 366. Dulau \& Co., London.

Towne IG, Barnard I. 2000. Themeda quadrivalvis (Poaceae: Andropogoneae) in Kansas: an exotic plant introduced from birdseed. Sida 19: 201-203.

Trinius CB. 1832. Andropogoneorum genera speciesque complures definitionibus novis. Mémoires de l'Academie Imperiale des Sciences de St.Petersbourg. Sixieme Serie. Sciences Mathematiques, Physiques et Naturelles 2: 320-324.

Veldkamp JF. 1984. The identity of Andropogon nutans Linnaeus (Gramineae). Taxon 33: 95-97.

Veldkamp JF. 2015. Themeda barbata, the correct combination for Themeda japonica (Gramineae). Journal of Japanese Botany 90: 312-316.

Welker CAD, Souza-Chies TT, Longhi-Wagner HM, et al. 2015. Phylogenetic analysis of Saccharum s.I. (Poaceae; Andropogoneae), with emphasis on the circumscription of the South American species. American Journal of Botany 102: 248-263.

Willdenow CL. 1806. Species plantarum, ed. 4, 4, 2: 899-902. Nauk, Berlin. Zhao N[X]. 1998. A study on the systematics of the genus Themeda Forsskal. Journal of Tropical and Subtropical Botany 6: 293-308

Zhuang T-D, Chen S-L. 1989. New taxa of genus Themeda Forsk. (Gramineae) from China. Bulletin of Botanical Research. Harbin 9: 55-66.

\section{INDEX TO SPECIMENS}

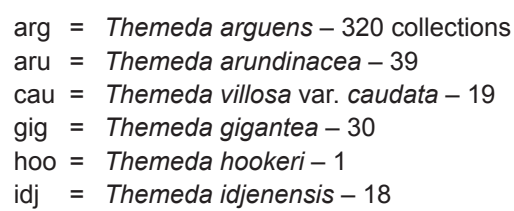

idj = Themeda idjenensis -18

\author{
$(\mathrm{T})$ = type \\ $(\mathrm{ST})=$ syntype \\ (V) = Voucher: Unpublished or invalid names \\ have no types, but 'vouchers'.
}

A 990 (Kadir): arg; 2690 (Kadir): arg; 3276 (Cuadra): cau - Adj. Veearts Gorontalo 3: arg - Aguilar 974: arg - Allen 8 Feb. 1950: arg - Amir 156: vil - Anta 645: vil - Argent \& Reynoso 89150: gig - Arsin 15 Nov. 1895: arg; 29: arg.

Backer June 1903: vil; June 1910: arg; Jan. 1911: vil; 1 May 1925: arg; 24 May 1927: idj; 9 June 1927: tri; 630: arg; 908: tri; 996: vil; 1087: arg; 1377: vil; 1886: vil; 2098: arg; 2347: vil; 2685: arg; 3016: arg; 3070: vil; 3430: vil; 3433: tri; 5019: vil; 5291: arg; 5456: vil; 5806: arg; 6250: arg; 7332 : arg; 7546: arg; 8142: arg; 8651: vil; 9411: vil; 10455: vil; 12068: vil; 12170: arg; 12985: arg; 13077: arg; 13217: arg; 13468: vil; 13483: arg; 13829: arg; 14113: vil; 14521: arg; 14813: vil; 15570: arg; 15954: arg; 17021: vil; 17242: vil; 17436: vil; 18515: vil; 20088: arg; 20187: tri; 21990: arg; 22327: arg; 23763: vil; 23879: arg; 24086: arg; 24250: arg; 24272: arg; 24314: arg; 24482: arg; 24812: arg; 24943: tri; 25076: tri; 25150 (V): idj; 25412: arg; 25729: vil; 27374: arg; 28018: arg; 28418: arg; 28779: arg; 29305: arg; 29707: arg; 30005: arg; 30786: tri; 33146: arg; 33147: arg; 35222: arg; 36015: ?idj; 36158: idj; 36825: arg; 36946 (V): idj; 37445: arg - Bakhuizen v.d. Brink C. 01012: arg; 49: arg; 66: vil; 429: arg; 431: arg; 1223: vil; 3499: vil; 3811: vil; 3827: arg; 3828: arg; 3856: vil; 5133: vil; 5134: arg - Balansa 16 Nov. 1886: arg, vil - Bartlett \& La Rue 392: vil - bb 9022 (Ostwald): vil; 9820 (Wind): vil; 11148 (Japing): vil; 12218 (Satridihardjo) (V): idj; 12309 (Roeloffs): vil; 12336 (Roeloffs): vil - Beccari PB 954: (pol) - Beguin 31: arg; 56: arg; 76: arg; 176: tri; 191: arg; 642: arg - Bell 20: tri - Bernstein 239: vil-Beumée 830: arg; 939: arg; 1396: vil; 1452: arg; 1594: vil; 1594a: cau; 2459: arg; 2656: arg; 2773: arg; 3434: vil; 3940: arg; 4143: arg - BF 29868 (Denaga): tri - Bicknell 219: vil - Bijhouwer 16 (V): idj; 244: arg Bloembergen 3323: arg; 3427: vil; 3733: tri; 3735: arg; 4049: vil - Boerlage 391: pol-Bouman III: qua-Brass 3518: gig; 3589: nov; 3692: tri; 3710 (T): nov; 3723: tri; 5927: tri; 6269: tri; 6382: pol; 6474: arg; 8782: nov; 11678: pol 27738: tri - Brinkman 82: arg - Bruggeman 618: vil - BS 1109 (Ramos): tri; 3632 (Fénix): gig; 4433 (Merrill): tri; 5131 (Ramos): tri; 10171 (McGregor): tri; 10188 (McGregor): tri; 11544 (Merrill): tri; 14194 (McGregor): tri; 21994 (Ramos): gig; 27566 (Ramos): gig; 30080 (Fénix): gig; 30288 (Ablaza): gig; 31981 (Santos): tri; 32692 (Ramos): tri; 36803 (Ramos \& Edaño): vil; 38468 (Ramos \& Edaño): tri; 41394 (Lopez): gig; 44578 (Ramos \& Edaño): gig; 44623 (Ramos \& Edaño): arg; 76821 (Ramos): gig - Bünnemeijer 56: vil; 215a: vil; 224: vil; 225: vil; 1397: arg; 1405a: arg; 1985: cau; 2991: vil; 3021: vil; 3518: vil; 4300: vil; 4301: vil; 4340: vil; 5194: vil; 5674: vil; 5881: pol; 6619: vil; 7002: vil; 7885: cau; 8021: vil; 8363: vil; 10616: vil; 10782: vil; 11029: vil; 11422: arg; 11688: arg - Burkill 1239: tri; 3289: vil; 3355: arg - Burtt 11287: vil - Buwalda 3013: arg; 3790: vil; 4840: arg; 6029: arg; 7517: tri; 8157: arg - Buysman 62: arg - BW 715 (Versteegh): arg. Carr 11133: tri; 11235: nov; 11967: pol - Carrick 1412: arg - Church et al. 1118: pol - Cinatti 228: ?vil-Civ. Gezagh. Taliwang 12: arg; 19: arg - Clason 
A-27: arg - Clason-Laarman E 49: idj; F 116 (V): idj - Clemens Mar. 1907: pol; 9808: pol; 21883: pol; 29171: aru - Clemens J. Apr. 1927: pol - Coert 6: arg; 520: arg; 679: idj - Colfs 308: aru - Coode 5823: arg - Craven \& Schodde 1393: pol - Cuming 1272 (ST): aru; 1673 (T): tri; 1873 = 1673; 6091 (T): pol - Curtis 1911: arg; 1971: vil.

Dammerman 9: arg - Danser 5344: arg - Darbyshire 723: pol - De Boer 4: arg - De Geer June 1965: arg - De Haan 153: arg - De la Savinière 190: arg; 209: arg; 1583: arg - De Mol 143: arg - De Voogd 1516: vil; 1753: arg; 1965: arg; 2236: arg; 2422: arg; 2518: tri; 2617: tri - De Wilde 2947: arg - De Wilde \& De Wilde-Duyfjes 12824: vil; 16442: arg - De Wilde \& Vervoort 409: arg - De Wit 4048: vil; 4191: arg; 4288: arg - Den Berger 21 Aug. 1920: tri - Dihm 1 Sept. 1899: arg; 4: vil; 115: vil - Djadoet 1078: arg - Djamhari 30: arg - Docters van Leeuwen-Reijnvaan 20 May 1909: arg; 835: tri; 2539: vil - Dorgelo Bawean 110: arg - Dransfield S et al. 1272: vil - Duaneh 177: aru - Duistermaat \& Hillier S 046: vil - Duistermaat et al. WC-14: cau

Edeling Nov. 1863: vil; Mar. 1865: vil; May 1868: arg - Elbert 4330: vil; 4467 pol; 4502: pol; 4558: tri - Elly ?5: arg - Elmer 5764: tri (P); 11000: pol; 16764: gig - Endert 1832: vil; 5031: vil - Enoh 184: arg; 385: arg; 386: pol - Everaarts 43: arg - Everaarts \& Yusuf 25: arg - Eyma 1086: vil; 1202: cau, tri; 1468: cau; 4049: vil.

Fairchild 24: arg, tri - FB 8744 (Merritt): tri; 16852 (Curran): tri; 18154 (Curran et al.): tri; 29533 (Paraiso): tri; 30188 (Lagasca): tri - Fielding 4103: arg - FMS 13264 (Hamid): vil; 13989 (Strugnell): vil; 22254 (Symington): arg Forman \& Blewett 1048: vil - Franck 88: arg; 100: arg; 126: vil - Frenckel 13 May 1930: idj - FRI 51913 (Duistermaat et al.): vil; 53060 (Yao et al.): vil; 53154 (Yao et al.): vil; 55788 (Yao et al.): vil; 59831 (Rosdi \& Radifah): vil; 65275 (Yao et al.): vil - Friedberg 300: vil - Furtado 18 June 1931: vil. Gabriel 447: arg - Gianno E 304: vil - Gilliland 20 Aug. 1961: arg; 5120: arg; 5154: vil; 5284: vil - Goetghebeur \& Coppejans 3469: arg - Goodenough 1256: vil; 1300: arg - Gouv. Veearts Soembawa Jan. 1930: pol, tri; 19: arg - Grutterink 3161: arg.

Hallier f. 45: vil; 148a: vil; 601a: vil; 613a: arg; 613b: arg - Hamzah 18: tri - Haviland Apr. 1890: aru - Hennipman 5042: arg - Heyligers 1277: nov - Hidayat 37: arg; 202: arg - Hochreutiner 1678: vil; 2189: arg - Hoekstra 11: tri - Hollrung 275: tri - Holttum 12 Sept. 1938: vil; 21 Oct. 1946: arg Hoogerwerf June 1954: arg; 14: arg; 68: vil; 200: arg - Hoogland 883: pol; 3400: pol; 3892: tri; 4299: pol; 4670: tri; 4855: arg - Hoogland \& Pullen 5325: pol; 5411: tri; 5984: tri - Hose 70: arg - Houtv. NW Wirosari 3434: vil - Houwing Koedoes 20: arg; 689: arg; 951: arg - Huitema 70: ?vil; 110: vil - Hullett 23 Feb. 1892: arg.

Ibrahim \& Chin 218: vil - Iwatsuki et al. S-1572: vil.

Jaag 61: vil; 62: tri; 998: pol - Jacobson Dec. 1916: arg, vil - Jeswiet 188: arg; 704: arg; 907: arg; 1058: idj; 1630: vil; 1940: idj - Jochems 3098: arg. Kasik 69: arg - Kaudern 1551: aru - Kawakami 6 Oct. 1911: aru - KEP 19836 (?Mudun): arg - Kern 7231: arg - Kievits Banjoemas 1438: arg; Banjoemas 2272: arg; Banjoemas 2355: arg; 2724: arg; 2815: arg; 2817 : arg - Kjellberg 154: vil; 3725: pol - Kleinhoonte 138: arg - Knaap 1: vil; 9: tri; 14: arg - Koens 80: arg - Kooper 11 Oct. 1932: vil - Koorders 15100: vil; 17223: arg; 17224: arg; 21214: arg; 22306: vil; 23303: arg; 26692: vil; 27757: arg; 28287: arg; 28291: vil; 28303: arg; 31388: vil; 31398: arg; 34557: arg; 35292: arg; 35813: arg; 37579: tri; 37580: tri; 41129 : tri; 42922 (T): idj - Kooy 768: vil - Kostermans 21730: pol; 22020: tri - Kostermans \& Wirawan 372: qua - Koyama T-61097: aru; T-62061: tri - Kulescha Pekalongan 23: arg

L.Y.K. Dec. 1967: arg - Laegaard \& Norsangsri 21645B: cau - Lahiru SING 2010-161: arg - Lai 297: vil - Lais 14: aru - Lam 3328: pol - Lambinon 87/98: tri; 87/126: nov; 87/373: arg - Landbouwl. Besoeki 11: tri-Landbwl. Djokja en Ond. Kedoe 27: arg - Larsen 8114: tri; 8146: arg; 8844: vil; 9436 : arg - Larsen et al. 2102: vil - Laumonier 6525: vil - Lauterbach 319: tri; 1320; pol - Lazarides 7488: aru - Leach \& Dunlop 3747: (arg) - Leefmans 21 Apr. 1924: arg; 23 Apr. 1924: arg; 87: arg - Loher 7167: gig; 7212: gig Lörzing 476: arg; 916: vil; 1627: vil; 1647: arg; 1878: arg; 2506: vil; 3367 : arg; 3397: vil; 3566: vil; 3734: arg; 4842: arg; 4846: vil; 4981: vil; 6630: vil; 6670: vil; 8338: vil; 8581: vil; 9015: aru; 9105: vil; 9346: vil; 9689: vil; 11081: arg; 12498: vil; 12895: arg; 13010: vil; 14349: vil; 14483: vil; 15580: vil - Lot Obimantri 2170: aru - Lugas 161: aru; 1660: aru; 2479: aru

Mahyar et al. 1118: aru - Maidum 14: aru - Mawardi 36: arg - Maxwell 741018: aru; 76-690: arg; 80-206: vil; 86-960: arg; 90-1355: tri; 92-568: hoo; 95-712: tri; 97-1233: tri - McDonald \& Sunaryo 4434: tri - McKee 1302; pol; 1557: arg - Mehra 15: vil - Meijer 273: arg; 9186: vil; 9194: vil; 9262: arg - Meijer \& Noerta 9084: arg - Meijer Drees 143: tri - Merrill 2314: gig Metzner 109: vil - Middleton et al. 2060: vil - Mitchell 8520: tri - Mitchell \& Pane 5327: tri; 5329: arg - Molhuijsen Apr. 1912: arg - Monod de Froideville 592: arg; 748a; vil; 748b: vil; 930: arg; 946: cau; 1125: tri; 1207: tri; 1254 : arg; 1291: arg; 1356: arg; 1424: tri; 1495a: tri; 1517: tri; 1680: arg; 1684: tri; 1689: tri; 1690: pol; 1739: tri; 1750: tri; 1754: tri; 1781: tri; 1782: arg; 1813: tri; 1838: vil; 1845: tri; 1912: tri; 1916: arg; 1994: arg; 2009: arg; 2013: tri; 2014: tri - Mousset 12: arg - Müller 8 Aug. 1897: arg; 12: arg - Mulyati 78: vil - Murata \& Fukuoka J-370: arg - Murata \& Iwatsuki J-55: vil; J-63: arg Murata et al. B-206: vil; B-212: vil; J-1024: arg; J-1705: arg; T-41624: pol. Nakada 2359: arg - Nauen 20 June 1941: arg, vil - Nedi \& Idjan 138: arg - Neth. Ind. For. Service 59: aru - NGF 1162 (Smith): pol; 2949 (-): pol; 3302 (Womersley): tri; 3943: (Fryar): tri; 6188 (Womersley et al.): tri; 8784 (Womersley \& Jones): arg; 22065 (Gillison): nov; 33547 (Ridsdale): arg 35674 (Streimann \& Kairo): pol; 47730 (Streimann \& Kairo): pol - Noltée 1269: vil - Noorudin 6765: arg - Nurainas \& Veldkamp 2360: arg.

Oersipuny 13: tri; 25: tri - Ophof \& De Wit 20: arg.

Peekel 194: arg - Petrmitr 392: tri - Pleyte 78: arg - PNH 21790 (Edaño): gig; 72644 (Conklin \& Del Rosario): gig; 78734 (Conklin \& Buwaya): gig - Popta 68138/9: arg - Posthumus 2348: vil; 2658: tri; 2764: tri; 3095: vil - PPI 16309 (Snow \& Sagcal): pol; 18444 (Garcia et al.): gig; 18885 (Barbon et al.): gig; 21295 (Reynoso et al.): gig; 26679 (Gaerlan et al.): tri; 37636 (Romero \& Fuentes): tri - Pring(g)o Atmodjo 133: vil - Proefstation voor de Javasuikerindustrie 69: cau - Proppe 17: vil - Pullen 6711: nov; 6949: arg; 7237-A: arg; 7606: nov.

Raap 5: vil; 38: arg - Rahmat si Boeea 10821: vil - Rahmat si Toeroes 4380: vil - Ramos 1868: arg - Ramos Philipp. PI. 127: gig; 172: tri; 1864 (V): gig - Rant 276: pol - Rappard C, 23 Mar. 1949: idj; 1.I: arg; 43.IV: arg; 310: idj - Raynal 16705: arg; 16969: pol - Reinwardt 22: arg; 1297: arg - Reyne Mar. 1932: vil - Ridley 26 May 1890: vil; 53: vil; 446: vil; 1324: vil; 2822: vil; 10002: arg; 11682: pol; 14033: aru; 14845: vil - Ridsdale 1512: gig; 2452 : arg - Robinson PI. Rumph. Amboin. 42: arg - Roesel 212: arg - Rutten 1683: pol - Ruttner 99: vil

S 46297 (Yii \& Othman): aru - Saakov 18: vil; 43: tri - Samsuri 267: vil - SAN 82695 (Leopold \& Saikeh): aru; 82900 (Fernando): vil; 91005 (Gibot): aru 101404 (Jimpin): aru; 118218 (Amin \& Jarius): aru; 119850 (Amin et al.): aru; 150540 (Suzanna et al.): aru; 151185 (Laegaard et al.): pol; 151327 (Laegaard et al.): pol; 153304 (Veldkamp): vil; 153306 (Veldkamp): aru Sands 587: vil; 6650: arg - Santos J.V. 4009: gig; 4967: pol; 5134: aru 5303: gig; 5743: gig; 6583: pol; 6772: aru; 6706: tri; 6808: aru; 6926: gig 7118: gig; 7755: arg; 7806: arg - Santoso \& Pratama 41: vil - Saunders 82: tri - Scheffer 8 Nov. 1870: arg - Schiffner 1504: arg; 1506: arg; 1515 arg; 1586: vil; 1587: arg - Schmutz 1493: arg; 1533: pol; 4954: pol; 5837: pol - Schodde 2789: nov; 2843: tri - Seidenschwarz 06-01: gig - Seimund Nov. 1920: cau - Selvi et al. 7: vil - SF 4053 (Haniff \& ?): vil; 4621 (Burkill): arg; 10152 (Henderson): vil; 11523 (Machado): vil; 13102 (Burkill \& Haniff): vil; 19377 (Henderson): vil; 20286 (Henderson): arg; 20531 (Symington): vil; 22675 (Henderson): cau; 24655 (Holttum): vil; 29594 (Henderson): cau; 29902 (Corner): cau; 30763 (Corner): arg; 34413 (Nur): vil; 38214 (Henderson): vil - Shah 30: arg - Shah \& Ali 4204: arg - Shimizu et al. T-8882: aru - Sinclair 10 Dec. 1949: vil; 28 Jan. 1950: arg - Sirimongkol 169: cau - Siwon 1032: arg; 1050: vil; 1055: vil - Smitinand 1288: vil - Soejatmi 30 Nov. 1975: vil; 248: vil; 324: vil; 330: vil; 401: cau; 402: vil; 408b: vil; 412: tri; 413: vil - Soekisman 2: cau; 67: arg - Soewarta 45: vil - Sohns 37: arg Soibeh 384: aru - Sørensen 1747: tri - SP 6602 (Rimi et al.): vil - Stomps A०1923: arg - Stone 14058: arg - Stoutjesdijk 33: arg - Street \& Manner 42: pol; 108: tri - Sukkri 80: pol - Sumadijaya 703: arg.

Tagawa et al. T-370: cau; T-9268: aru; T-10518: aru - Takeuchi et al. 13075 arg - Taylor 2278c: pol; 2646b: pol; 2646d: pol - Teijsmann 13746: vil; 14089: ?vil; HB 2059: arg; HB 4910: vil; HB 4921: arg; HB 4922: vil Tuxen 6: arg.

Ultée 4: arg; 25: arg - Uway et al. 10 Feb. 1989: vil.

Van Balgooy 5093: tri - Van Balgooy \& Mamesah 6369: arg - Van Borssum Waalkes 2512: vil - Van der Goot 4: arg - Van der Meer 72: vil - Van der Meer \& Den Hoed 2080: arg - Van der Paardt 2: idj; 7: tri; 8: arg - Van der Voort 24: vil - Van Leeuwen Kai 6: vil; Keb. 10: arg - Van Loenen 16 (T): aru - Van Maarsenveen 1: arg - Van Ooststroom 12509: arg; 12956: arg; 13169: vil - Van Royen 5136: tri - Van Royen \& Sleumer 5662: tri - Van Steenis 878: arg; 7608: arg; 7760: tri; 7763a (T): arg; 8025: tri; 11406: arg; 11407a: tri; 11569: tri; 12076: tri; 17895: tri; 18089: pol; 18127: tri - Van Thull 12: arg - Vanoverbergh 301: arg; 410: gig; 901: arg; 1568: tri (P); 1581: (gig) - Varadarajan et al. 1509: gig - Veearts Sibolga 32: arg - Veemantri Dj. 18: arg; 21: arg - Veldkamp \& Stevens 5506a: pol - Verboom 34: vil - Verheijen 751: vil; 3864: qua; 4894: arg; 4949: vil - Vermeulen 9: arg; 2397: pol - Vesterdal 449: aru - Vorderman a5: arg; 122: arg; 166: arg. Walsh 5: tri; 28: arg; 36: tri; 40: arg - Waterhouse 952: pol - Watson I. 12: tri - Westendorp 20 July 1936: arg - Widjaja 91: vil; 115: vil; 142: pol; 221: vil; 470: vil; 552: vil; 1044: tri; 2907: tri; 2970: arg; 4689: arg - Widjaja \& Hamzah 2907: arg; 9966: tri; 9971: vil - Widjaja et al. 9536: vil - Winckel 11 July 1917: arg; 43: arg; 761: arg; 1028: vil; 1467: vil - Winkler 1581: pol - Wiriadinata 45: tri; 3982: vil - Wirjahardja 6D7: arg - Wisse 841 arg; 842: tri; 868: vil; 1071: arg - Wöhler 13: tri - Wolff von Wülfing 1232: vil - Worthington 12386: vil.

Yakob 24: arg - Yapp 89: aru, vil - Yates 1254: arg - Yoshida 905: vil; 1754: arg; 2084: vil.

Zollinger 373 (T): arg; 1029 (T): vil. 